\title{
Biohydrogen production from hyperthermophilic anaerobic digestion of fruit and vegetable wastes in seawater: Simplification of the culture medium of Thermotoga maritima
}

\author{
Rafika Saidi ${ }^{\text {a,c }}$, Pierre Pol Liebgott ${ }^{c}$, Hana Gannoun ${ }^{\text {a,b }}$, Lamia Ben Gaida ${ }^{\text {a,b }}$, Baligh Miladi a , \\ Moktar Hamdi ${ }^{a}$, Hassib Bouallagui ${ }^{a}$, Richard Auria ${ }^{\mathrm{c}, *}$ \\ a Université de Carthage, Laboratoire d'Ecologie et de Technologie Microbienne LETMi, INSAT, B.P. 676, 1080 Tunis, Tunisia \\ ${ }^{\mathrm{b}}$ Université de Tunis El Manar, ISSBAT, 9 Avenue Zouhaïer-Essafi, 1006 Tunis, Tunisia \\ ' Aix Marseille Université, CNRS, Université de Toulon, IRD, MIO UM 110, 13288 Marseille, France
}

\section{A R T I C L E I N F O}

\section{Article history:}

Received 3 July 2017

Revised 26 September 2017

Accepted 29 September 2017

Available online 10 October 2017

\section{Keywords:}

Biohydrogen

Fruit and vegetable wastes

Thermotoga maritima

Natural seawater

Hyperthermophilic anaerobic digestion

\begin{abstract}
A B S T R A C T
Biohydrogen production by the hyperthermophilic and halophilic bacterium $T$. maritima, using fruit and vegetable wastes as the carbon and energy sources was studied. Batch fermentation cultures showed that the use of a culture medium containing natural seawater and fruit and vegetable wastes can replace certain components $\left(\mathrm{CaCl}_{2}, \mathrm{MgCl}_{2}\right.$, Balch's oligo-elements, yeast extract, $\mathrm{KH}_{2} \mathrm{PO}_{4}$ and $\left.\mathrm{K}_{2} \mathrm{HPO}_{4}\right)$ present in basal medium. However, a source of nitrogen and sulfur remained necessary for biohydrogen production. When fruit and vegetable waste collected from a wholesale market landfill was used, no decreases in total $\mathrm{H}_{2}$ production $\left(139 \mathrm{mmol} \mathrm{L}^{-1}\right.$ ) or $\mathrm{H}_{2}$ yield $\left(3.46 \mathrm{~mol} \mathrm{~mol}^{-1}\right.$ ) was observed.
\end{abstract}

\section{Introduction}

The increasing world population and greater average per capita income have led to a rise in energy consumption, amounting to 553 $\times 10^{15} \mathrm{~kJ}$ in 2010 . Currently $80 \%$ of most global energy demands are met by fossil fuels, such as oil, coal, and natural gas as main energy sources. Increasing energy demands will accelerate the depletion of fossil fuels, which in turn will raise energy costs and adversely affect national economies (Shafiee and Topal, 2009). Moreover, dependence on fossil fuels has created many environmental problems (e.g. emission of greenhouse gases and pollutants). This situation has prompted the development of renewable energy sources which are expected to provide a solution to the double challenge of environmental restoration and energy security (Turner, 2004). Renewable energy sources such as solar, wind, thermal, hydroelectric and biomass have thus recently attracted much interest internationally

Particular attention is being focused on research into hydrogen production and conservation. The use of hydrogen shows a $10 \%$ growth per year, leading to represent $8-10 \%$ of total energy in

\footnotetext{
* Corresponding author.

E-mail address: richard.auria@mio.osupytheas.fr (R. Auria).
}

2025. Today, hydrogen is almost exclusively used for industrial purposes in chemicals and refining. Hydrogen $\left(\mathrm{H}_{2}\right)$ is an attractive, clean future energy vector, and has the highest energy content per weight ( $143 \mathrm{~kJ} / \mathrm{g}$, against $54 \mathrm{~kJ} / \mathrm{g}$ for methane, $29.7 \mathrm{~kJ} / \mathrm{g}$ for ethanol and $47.3 \mathrm{~kJ} / \mathrm{g}$ for gasoline). It can be easily and directly converted into water and electrical current (55-60\%) in fuel cells. This electrical current can have a wide range of applications from transportation fuel to electricity generation (Mason and Zweibel, 2007). Hydrogen is currently generated by fossil resources, but it can also be produced from non-fossil fuel resources such as water by electrolysis, thermochemical processes, radiolytic processes, and biological processes (Chandrasekhar et al., 2015).

Biological processes such as photofermentation, dark fermentation and biophotolysis are environmentally friendly methods, and have low investment costs (Argun et al., 2017; Pathak et al., 2016). Anaerobic fermentation, also known as dark fermentation, seems a promising alternative for producing hydrogen in view of its high rates of hydrogen production, its low energy requirements, its feasibility (light-independent catabolic process), and its use of renewable feedstock sources (wastes, wastewaters or insoluble cellulosic materials) (Ramírez-Morales et al., 2015; Cardoso et al., 2014; Ruggeri and Tommasi, 2012; Das et al., 2014). Theoretically, the dark fermentation of $1 \mathrm{~mol}$ of glucose yields $4 \mathrm{~mol}$ of $\mathrm{H}_{2}$ or 2 mol of $\mathrm{H}_{2}$ through acetate or butyrate pathways (Kanchanasutaa 
et al., 2016). Several factors influence the fermentative hydrogen production process, such as type and pre-treatment of inoculum, substrate, type of reactor configuration, $\mathrm{pH}$ and temperature (De Gioannis et al., 2013).

The highest fermentative $\mathrm{H}_{2}$ yields have been obtained with (hyper)thermophilic $\mathrm{H}_{2}$ producers belonging to archaeal and bacterial domains (Guo et al., 2010; Cappelletti et al., 2012; Pradhan et al., 2015). They offer many advantages, such as lower viscosity of media, higher hydrogen production rates, less contamination level by $\mathrm{H}_{2}$-consuming microorganisms and enhanced hydrolysis rates of complex substrates (Mohan, 2010; Pradhan et al., 2015). Some members of the order Thermotogales have been considered as ideal organisms for the industrial bioconversion of large quantities of waste materials into fuels. They allow high $\mathrm{H}_{2}$ yields, ranging from 1.5 to $3.85 \mathrm{~mol} \mathrm{H}_{2} \mathrm{~mol}^{-1}$ hexoses from various carbohydrate-rich wastes (Cappelletti et al., 2012). Furthermore, de Vrije et al. (2009) showed that the rate of substrate consumption, biomass density and $\mathrm{H}_{2}$ production of $T$. neapolitana were higher on the Miscanthus hydrolysate than on pure sugars (glucose/xylose). They have obtained a maximal volumetric hydrogen productivity of $12.6 \mathrm{mmol} \mathrm{h}^{-1} \mathrm{~L}^{-1}$ when $T$. neapolitana was fermenting $10 \mathrm{~g} \mathrm{~L}^{-1}$ of Miscanthus hydrolysates. These results could be attributed to the supplementation of the medium with some nutrients originating from the hydrolysate. The volumetric hydrogen productivity and the hydrogen yield of Thermotoga neapolitana with $10 \mathrm{~g} \mathrm{~L}^{-1}$ sugars from carrot pulp hydrolysate were $12.5 \mathrm{mmol}$ $\mathrm{h}^{-1} \mathrm{~L}^{-1}$ and $2.8 \mathrm{~mol} \mathrm{H}_{2} \mathrm{~mol}^{-1}$ hexose, respectively (de Vrije et al., 2010).

In recent years, pure cultures of Thermotoga maritima have attracted considerable interest for their potential to produce hydrogen from many simple and complex carbohydrates (Huber et al., 1986; Chhabra, 2003; Nguyen et al., 2008; Boileau et al., 2016). This bacterium contains a wide range of thermostable hydrolytic enzymes (cellulases, invertase and xylanases), which are important for hydrolyzing the carbohydrate polymers into monomer sugars (Cappelletti et al., 2012).

Fruit and vegetable wastes (FVW) are produced in large quantities in wholesale markets; they raise serious environmental concerns, being rapidly contaminated during landfill disposal, especially after mechanical damage. In Tunisia, about 2.5 million tons per year of municipal solid wastes is generated, with an annual increase of about $2.5 \%$. These wastes, characterized by a high moisture content (65\%), consist mainly of a biodegradable organic fraction in the form of FVW (68\%) (ANGED, 2016). The port of Tunis, with one quarter of the country's population, receives about 400 thousand tons of FVW per year $(20 \%$ of the national wholesale production). Most wastes (25 tons per day) are transferred to landfills for burial or incineration without energy recovery, resulting in odor and toxic gas emissions, water pollution and costlier municipal landfills. Fermentative hydrogen production from FVW is widely recognized as an important strategy to reduce the escalating cost of landfill. Given their high organic content (75\%) and ready biodegradability, FVW can be used as carbon and energy sources biofuel production (Bouallagui et al., 2009, 2005; Garcia-Peña et al., 2011; Mohan, 2010).

To our knowledge, no studies have been carried out with seawater as culture medium for biohydrogen production. One of the advantages of using seawater is to reduce fresh water losses knowing that less of $1 \%$ of the world's fresh water is accessible for human uses. Wu et al. (1993) have shown that the outdoor cultivation of Spirulina in seawater culture medium has potential for industrial production and has several advantages over its production in freshwater. It does not involve valuable farm land and employ less expensive culture. These results were confirmed by Leema et al. (2010) who have explained the advantage to use seawater media for the cultivation of Arthrospira (Spirulina) platensis at very low cost.

The main goal of this work was to study the feasibility of hyperthermophilic $\mathrm{H}_{2}$ production from fruit and vegetable wastes by Thermotoga maritima in a simplified low-cost culture medium. The addition of natural seawater as an inorganic compound source was evaluated on the total $\mathrm{H}_{2}$ production. The growth medium composition was simplified and optimized to achieve efficient $\mathrm{H}_{2}$ production process from FVW harvested directly from landfill sites in Tunisia.

\section{Material and methods}

\subsection{Strain and medium}

The microorganism used in this study was the type strain of Thermotoga maritima DSM 3109 obtained from the Deutsche Sammlung von Mikroorganismen und Zellkulturen (DSMZ). Two mineral media were used to grow T. maritima that differed in their composition by the water used as solvent. A mineral basal medium (MBM) was made up with distilled water, while a natural seawater medium (NSM) was made with natural seawater taken directly from the bay of Gammarth located 15-20 km north of Tunis. This natural seawater was filtered under vacuum through a $0.45 \mu \mathrm{m}$ cellulose nitrate filter (Sartorius, Germany).

The composition of the two media was $\left(\mathrm{g} \mathrm{L}^{-1}\right)$ : $\mathrm{NH}_{4} \mathrm{Cl}$ (1), yeast extract (1), cysteine $\mathrm{HCl}(0.3), \mathrm{KH}_{2} \mathrm{PO}_{4}(0.3), \mathrm{K}_{2} \mathrm{HPO}_{4}(0.3), \mathrm{NaCl}$ (25), $\mathrm{MgCl}_{2}$ (0.25), $\mathrm{KCl}(0.5), \mathrm{CaCl}_{2}$ (0.1), and $10 \mathrm{~mL}$ Balch's oligoelements solution. Balch's solution ( $\mathrm{pH} 6.5)$ contained $\left(\mathrm{g} \mathrm{L}^{-1}\right)$ : nitrilotriacetic acid (1.5), $\mathrm{MgSO}_{4} \cdot 7 \mathrm{H}_{2} \mathrm{O}(3.0), \mathrm{MnSO}_{4} \cdot \mathrm{H}_{2} \mathrm{O}(0.5), \mathrm{NaCl}$ (1), $\mathrm{FeSO}_{4} \cdot 7 \mathrm{H}_{2} \mathrm{O}(0.1), \mathrm{CoSO}_{4} \cdot 7 \mathrm{H}_{2} \mathrm{O}(0.18), \mathrm{CaCl}_{2} \cdot 2 \mathrm{H}_{2} \mathrm{O}(0.1), \mathrm{ZnSO}_{4}-$ $.7 \mathrm{H}_{2} \mathrm{O}(0.18), \mathrm{CuSO}_{4} \cdot 7 \mathrm{H}_{2} \mathrm{O}(0.01), \mathrm{KAl}\left(\mathrm{SO}_{4}\right)_{2} \cdot 12 \mathrm{H}_{2} \mathrm{O}(0.02), \mathrm{H}_{3} \mathrm{BO}_{3}$ (0.01), $\mathrm{Na}_{2} \mathrm{MoO}_{4} \cdot 2 \mathrm{H}_{2} \mathrm{O}(0.01), \mathrm{NiCl}_{2} \cdot 6 \mathrm{H}_{2} \mathrm{O}(0.025), \mathrm{Na}_{2} \mathrm{SeO}_{3} \cdot 5 \mathrm{H}_{2} \mathrm{O}$ (0.0003), $\mathrm{Na}_{2} \mathrm{WO}_{4} \cdot 2 \mathrm{H}_{2} \mathrm{O}$ (0.0112) (Boileau et al., 2016).

\subsection{Feedstocks: sampling, preparation and characterization}

Two feedstocks were used in this study: (i) Model Fruit and Vegetable Wastes (MFVW), whose main constituents $(\mathrm{g} / \mathrm{kg})$ were: plums (207), peaches (207), apples (207), carrots (138), potatoes (130) and tomatoes (110), and (ii) Fruit and vegetable wastes (FVW) directly collected in a landfill near the Bir Kassa wholesale market of Tunis, in the winter season. The composition of FVW varied, reflecting the average production of these wastes in the wholesale market of Tunis during the winter season (apples, carrots, potatoes, tomatoes, pears, oranges, tangerines, onions, fennel, spinach and parsley, etc.). The two feedstocks were crushed with an electric blender into small pieces measuring less than about 2 $\mathrm{mm}$ in length and width, filtered, fully mixed and directly stored at $-20^{\circ} \mathrm{C}$ for later use.

\subsection{Experimental system}

The batch fermentation cultures of $T$. maritima for biohydrogen production were conducted in anaerobic conditions in a continuously stirred tank reactor (CSTR). A schematic diagram of the experimental process is shown in Fig. 1. The CSTR was composed of a $2.5 \mathrm{~L}$ glass vessel with a double envelope jacket for temperature regulation and a stainless steel lid with septum. The bioreactor was heated $\left(80 \pm 0.5^{\circ} \mathrm{C}\right)$ by thermal recirculation of water in the jacket using a heat bath (Polystat 37, Fisher Scientific). The bioreactor was stirred at $150 \mathrm{rpm}$ with an electric motor (IKA EUROSTAR 20 digital) and was equipped with $\mathrm{pH}$ and redox probes (Mettler Toledo InPro 3253, Switzerland), calibrated at $80^{\circ} \mathrm{C}$ before 


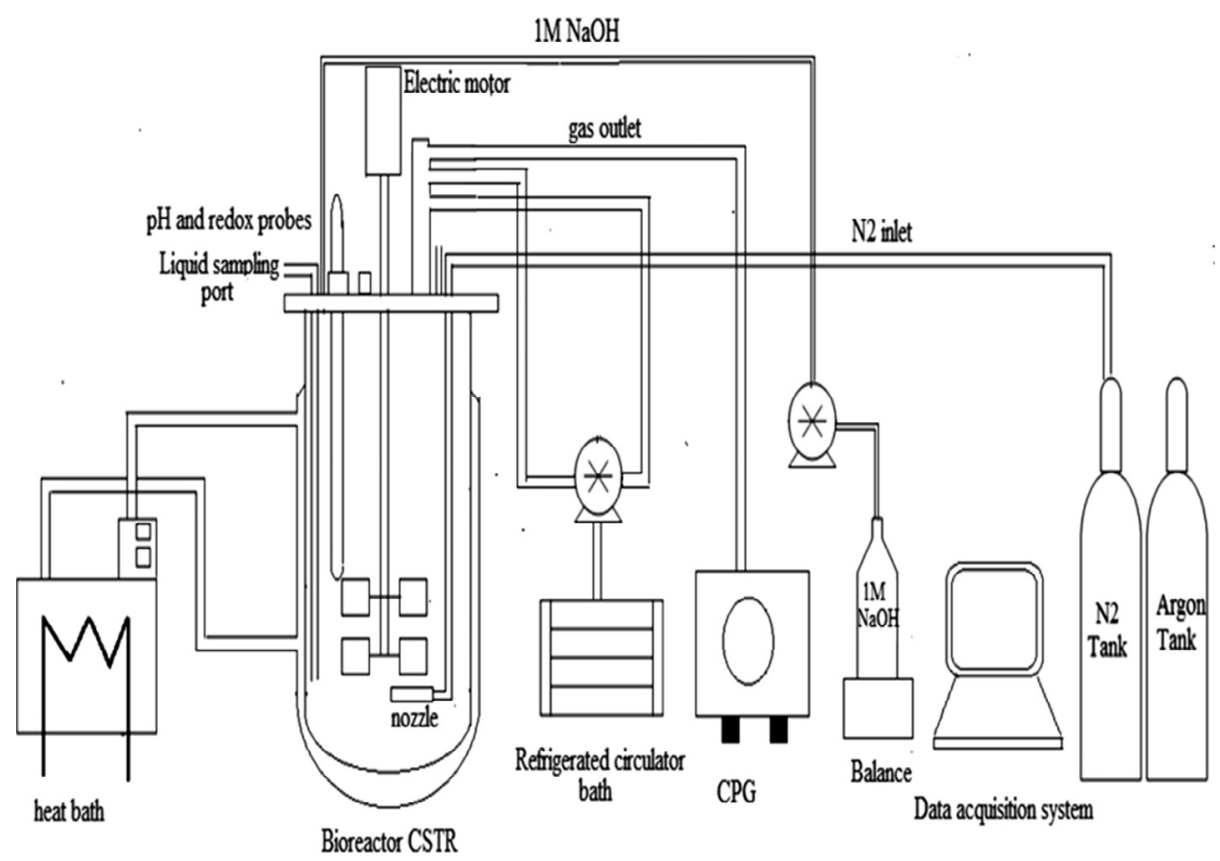

Fig. 1. Schematic representation of the $\mathrm{H}_{2}$ experimental process composed of the bioreactor, heat bath, condenser, pH regulation and GC analyser.

fermentation as described by Lakhal et al. (2011). The regulation of $\mathrm{pH}$ at $7.0 \pm 0.1$ in the bioreactor was automatic, by adding $1 \mathrm{M}$ $\mathrm{NaOH}$ whose consumption was tracked by a balance (AE Adam, France).

Anaerobic conditions were maintained by continuous injection of a stream of pure $\mathrm{N}_{2}$ at $50 \mathrm{~mL} \mathrm{~min}^{-1}$ through a nozzle immersed in the bottom of the bioreactor. The $\mathrm{N}_{2}$ gas inlet was equipped with a $0.20 \mu \mathrm{m}$ PTFE membrane filter (Midisart ${ }^{\circledR}$ 2000 , Sartorius Stedim) to sterilize the gas. To prevent loss of liquid caused by the high temperature, the outlet gas was condensed in a water cooler (PTC-2 Peltier Temperature Controller) whose temperature was controlled at around $7{ }^{\circ} \mathrm{C}$ with a refrigerated circulator bath equipped with a pump. The composition of outlet gas $\left(\mathrm{H}_{2}\right.$ and $\left.\mathrm{N}_{2}\right)$ was measured at regular intervals (30 min) by automatically taking $1 \mathrm{~mL}$ from the headspace of CSTR and injecting it into the GC (Gas Chromatograph) via a valve. The $\mathrm{CO}_{2}$ content in the outlet gas stream was measured in-line using a carbon dioxide probe (Vaisala Series GMT221, Finland) connected to a transmitter.

T. maritima was batch-cultured in a 2.2-L double-jacket glass bioreactor (FairMenTec, France) with a 1.1-L working volume. Before inoculation, the bioreactor was filled with the MBM, and $0.4 \mathrm{~g} \mathrm{~L}^{-1}$ of $\mathrm{Na}_{2} \mathrm{~S}$ was added. Experiments were set up by removing each of the nutrients one by one from the culture medium (Table 3) and evaluating impact on fermentative $\mathrm{H}_{2}$ production. Each experimental condition was run in triplicate successive fermentation cycles. For the fermentation cycle, the bioreactor was emptied under a pure $\mathrm{N}_{2}$ stream leaving a volume of $100 \mathrm{ml}$ of fermentation liquid necessary to inoculate the next fermentation cycle. New culture medium supplemented with adequate nutrients was added to this volume of $100 \mathrm{~mL}$, and a new fermentation cycle run.

\subsection{Analytical methods}

The total solids (TS), volatile solids (VS), total organic carbon, total nitrogen Kjeldahl (TNK), total chemical oxygen demand (tCOD), and the $\mathrm{pH}$ of the substrates were estimated according to APHA (2005). For total carbohydrate concentration, the anthrone- sulfuric acid method was used (Raunkjær et al., 1994) with modifications. A $0.2 \%$ solution of anthrone $(\mathrm{w} / \mathrm{v})$ was made up fresh in $75 \%(\mathrm{v} / \mathrm{v})$ sulfuric acid on the day of measurement. The procedure consists in mixing a $1 \mathrm{~mL}$ sample with $2 \mathrm{~mL} 75 \% \mathrm{H}_{2} \mathrm{SO}_{4}$ and $4 \mathrm{~mL}$ of anthrone reagent by vortex. Samples were placed on the heating block at $105^{\circ} \mathrm{C}$ for $15 \mathrm{~min}$ and then cooled down to room temperature. Absorbance of each sample was determined at $625 \mathrm{~nm}$ using a UV-visible spectrophotometer. Measurement of biomass concentration could not be carried out due to the fact that fruits and vegetables (MFVW or FVW) interfered with the measurement of OD or proteins.

The reducing sugar concentrations were measured according to the method described by James (2013). The lignocellulose characterization of substrates including cellulose and hemicelluloses was carried out with reference to a gravimetric method described by Sun et al. (2003). The experiments related to the lignocellulose characterization of substrates were done in triplicate.

The concentration of $\mathrm{H}_{2}$ in the bioreactor headspace was determined using a gas chromatograph (GC, Perichrom Company, France) equipped with a thermal conductivity detector (TCD) and a concentric CTR1 column (Alltech, USA). The operational temperatures of the detector, the injector and the oven were $100^{\circ} \mathrm{C}, 100{ }^{\circ} \mathrm{C}$ and $40^{\circ} \mathrm{C}$, respectively. Argon was used as the carrier gas at a flow rate of $20 \mathrm{~mL} \mathrm{~min}^{-1}$. This system was connected to a computer running WINILAB III software (Perichrom, France).

During fermentation, the concentrations of the main soluble metabolite products (acetate and lactate) and the residual sugars (sucrose, glucose and fructose) were measured. The liquid samples harvested from the CSTR were centrifuged at 14,000g for $5 \mathrm{~min}$. The supernatants obtained were then filtered through a $0.45 \mu \mathrm{m}$ cellulose acetate Minisart syringe filter (Sartorius Stedim). They were analyzed by HPLC (Agilent 1200 series, USA) equipped with a quaternary pump model coupled to a refractometer index (RI) detector and $300 \times 7.8 \mathrm{~mm}$ Aminex HPX-87 H ion-exchange columns (Bio-Rad). This HPLC was connected to a computer running WINILAB III software (Perichrom, France). Sulfuric acid $5 \mathrm{mmol}$ $\mathrm{L}^{-1}$ (in milliQ water) was used as mobile phase with a flow rate of $0.5 \mathrm{~mL} \mathrm{~min}^{-1}$. 
Table 1

Physical and chemical characterization of Fruit and Vegetable Wastes (FVW) and Model Fruit and Vegetable Wastes (MFVW).

\begin{tabular}{|c|c|c|}
\hline Parameter & MFVW & FVW \\
\hline Total solids (TS) (\% wb) & $10.1 \pm 0.1$ & $8.5 \pm 0.3$ \\
\hline Volatile solids (\%/TS) & $94.6 \pm 1.7$ & $92.7 \pm 2.3$ \\
\hline Total COD $\left(\mathrm{g} \mathrm{L}^{-1}\right)$ & $148 \pm 2.5$ & $129 \pm 6.3$ \\
\hline Particulate COD $\left(\mathrm{g} \mathrm{L}^{-1}\right)$ & $52 \pm 4.1$ & $38 \pm 4.6$ \\
\hline Soluble COD $\left(\mathrm{g} \mathrm{L}^{-1}\right)$ & $96 \pm 4$ & $91 \pm 4.3$ \\
\hline Total organic carbon $\left(\mathrm{g} \mathrm{L}^{-1}\right)$ & $103.6 \pm 4.5$ & $81.6 \pm 1.5$ \\
\hline Carbohydrates $\left(\mathrm{g} \mathrm{L}^{-1}\right)$ & $106 \pm 1.9$ & $97.2 \pm 1.8$ \\
\hline Total nitrogen Kjeldahl $\left(\mathrm{g} \mathrm{L}^{-1}\right)$ & $2.2 \pm 0.04$ & $2.5 \pm 0.1$ \\
\hline Reducing sugars $\left(\mathrm{g} \mathrm{L}^{-1}\right)$ & $83.5 \pm 5.6$ & $79.5 \pm 4.7$ \\
\hline $\mathrm{pH}$ & $4.07 \pm 0.09$ & $4.25 \pm 0.05$ \\
\hline Cellulose $\left(\mathrm{g} \mathrm{L}^{-1}\right)$ & 4. $5 \pm 0.7$ & $7.5 \pm 0.4$ \\
\hline Hemicellulose $\left(\mathrm{g} \mathrm{L}^{-1}\right)$ & $1.9 \pm 0.2$ & $2.5 \pm 0.1$ \\
\hline Reducing sugars (HPLC) $\left(\mathrm{g} \mathrm{L}^{-1}\right)$ & $84.1 \pm 0.3$ & $76.1 \pm 0.6$ \\
\hline
\end{tabular}

wb: wet basis.

2.5. Characteristics of the model fruit and vegetable wastes (MFVW) and fruit and vegetable wastes (FVW)

The characteristics of the MFVW and FVW are listed in Table 1. Total solid concentrations in MFVW and FVW were $10.1 \%$ and $8.5 \%$ with a total volatile solids content of about $94.6 \%$ and $92.7 \%$, respectively; $\mathrm{pH}$ was around 4 for both substrates. The total chemical oxygen demand (tCOD) and the total organic carbon (TOC) concentrations for the MFVW were 148 and $103.6 \mathrm{~g} \mathrm{~L}^{-1}$, respectively. These values were also high for the FVW (129 and $81.6 \mathrm{~g} \mathrm{~L}^{-1}$, respectively). However, the nitrogen content, quantified as total nitrogen Kjeldahl (TNK), was low for both substrates (around 2.5 $\mathrm{g} \mathrm{L}^{-1}$ ). The corresponding $\mathrm{C} / \mathrm{N}$ ratio of MFVW and FVW was balanced at around 47.1 and 33 , respectively. The organic fraction for MFVW and FVW consisted of a large amount of carbohydrates (106 and $97.2 \mathrm{~g} \mathrm{~L}^{-1}$, respectively), which have an important role during fermentative $\mathrm{H}_{2}$ production. The low amount of cellulose and hemicellulose in MFVW (4.5 and $1.9 \mathrm{~g} \mathrm{~L}^{-1}$ ) and in FVW (7.5, $2.5 \mathrm{~g} \mathrm{~L}^{-1}$ ) was explained by the waste centrifugation step to eliminate the solid phase and facilitate sampling during the batch fermentations. However, fruit and vegetable wastes are known to be cellulose-poor, are easily biodegradable and release volatile fatty acids (Bouallagui et al., 2005; Mohan, 2010). The concentration of reducing sugars in MFVW and FVW was about 83.5 and $79.5 \mathrm{~g}$ $\mathrm{L}^{-1}$, respectively.

\section{Results and discussion}

\subsection{Physical and chemical characterization of feedstocks}

For MFVW, the concentrations of reducing sugars obtained by HPLC were as follows: $163 \mathrm{mmol} \mathrm{L}^{-1}$ of glucose, $282 \mathrm{mmol} \mathrm{L}^{-1}$ of fructose and $22 \mathrm{mmol} \mathrm{L}^{-1}$ of sucrose for a total amount of about
$467 \mathrm{mmol} \mathrm{L}^{-1}$ (84.1 $\mathrm{g} \mathrm{L}^{-1}$ ) (Table 1). Total carbohydrate content of MFVW was about $106 \mathrm{~g} \mathrm{~L}^{-1}$ (588 $\mathrm{mmol} \mathrm{L}^{-1}$ equivalent glucose) (Table 1). The concentrations of reducing sugars and carbohydrates were also obtained from APRIFEL (2005) using the quantities of the different fruits and vegetables in the MFVW (Table 2). They were $86.7 \mathrm{~g} \mathrm{~L}^{-1}\left(481 \mathrm{mmol} \mathrm{L}^{-1}\right)$ and $114 \mathrm{~g} \mathrm{~L}^{-1}\left(633 \mathrm{mmol} \mathrm{L}^{-1}\right)$, respectively (Table 2).

Experimental concentrations of reducing sugars and total carbohydrate were comparable to those obtained from APRIFEL (2005). The differences between the concentrations of total carbohydrates and reducing sugars obtained from experiments (Table 1) and APRIFEL (2005) (Table 2) were about $22.5 \mathrm{~g} \mathrm{~L}^{-1}$ (125 mmol $\mathrm{L}^{-1}$ ) and $27.3 \mathrm{~g} \mathrm{~L}^{-1}\left(151.7 \mathrm{mmol} \mathrm{L}^{-1}\right)$. We note that except for potatoes, reducing sugar concentrations were equivalent to carbohydrate concentrations of the remaining constituents of MFVW (Table 2). Potatoes contain mainly carbohydrates such as starch, and very low concentrations of reducing sugars. Concentration of carbohydrates in potatoes is about $20 \mathrm{~g} \mathrm{~L}^{-1}\left(111.3 \mathrm{mmol} \mathrm{L}^{-1}\right)$ taking into account their water content (78.9\% wet basis) (Table 2 ). This concentration is comparable to those obtained experimentally (22.5 $\mathrm{g} \mathrm{L}^{-1}$ or $125 \mathrm{mmol} \mathrm{L}^{-1}$ ). It therefore seems that most of the carbohydrates came from the potatoes. Total solids (TS) (Table 1) of MFVW was about $117 \mathrm{~g} \mathrm{~L}^{-1}$ (considering a mean water content of MFVW of $85.2 \%$ (wet basis) (Table 2)). This value was lower than the average concentration of TS calculated from APRIFEL (2005), which was about $151.8 \mathrm{~g} \mathrm{~L}^{-1}$ (Table 2). This result seems correct because some fiber was removed after the centrifugation of MFVW.

FVW contained wastes obtained in the winter season, composed of citrus fruits (oranges and mandarins), apples and various vegetables (potatoes, carrots, tomatoes, onions, parsley, etc.). The heterogeneity of FVW from uncontrolled wastes precludes their characterization by APRIFEL (2005). The concentration of reducing sugars in FVW was about $79.5 \mathrm{~g} \mathrm{~L}^{-1}$, confirmed by measurements by HPLC $\left(76.1 \mathrm{~g} \mathrm{~L}^{-1}, 423 \mathrm{mmol} \mathrm{L}^{-1}\right.$ : glucose $182 \mathrm{mmol} \mathrm{L}^{-1}$, fructose $233 \mathrm{mmol} \mathrm{L}^{-1}$ and sucrose $\left.8 \mathrm{mmol} \mathrm{L}^{-1}\right)$. Carbohydrate concentration was about $97.2 \mathrm{~g} \mathrm{~L}^{-1}$ (540 $\mathrm{mmol} \mathrm{L}^{-1}$ equivalent glucose) (Table 1).

To evaluate the efficiency of fermentative $\mathrm{H}_{2}$ production from organic wastes by T. maritima, the indigenous fermentative communities in MFVW and FVW were evaluated in CSTR under hyperthermophilic conditions $\left(80^{\circ} \mathrm{C}\right)$. Some studies have demonstrated the feasibility of $\mathrm{H}_{2}$ production from self-fermentation of vegetables wastes without inoculum addition or pretreatments under mesophilic anaerobic conditions $\left(28^{\circ} \mathrm{C}\right.$ and $37^{\circ} \mathrm{C}$ ) (Marone et al., 2014). In our culture conditions, experiments in batch reactors with only NSW, FVW and all components necessary for the medium culture (negative control) were conducted. During these experiments, we did not obtain any production of hydrogen nor of other compounds (acetate and lactate) (data not shown). These results may be explained by the absence of indigenous extremophilic and/or halotolerant microflora able to produce $\mathrm{H} 2$ by dark fermentation.

Table 2

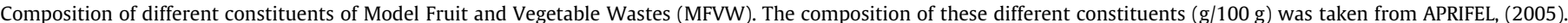

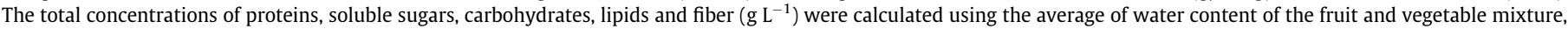
the concentration of each fruit or vegetable constituents $(\mathrm{g} / 100 \mathrm{~g})$ and the weight of each fruit or vegetable $\left(\mathrm{g} \mathrm{kg}^{-1}\right)$

\begin{tabular}{|c|c|c|c|c|c|c|c|c|}
\hline Constituent & Weight $\left(\mathrm{g} \mathrm{kg}^{-1}\right)$ & Water content (\% wb) & Proteins & Soluble sugars & Carbohydrates & Lipids & Fiber & Organic acids \\
\hline Plums & 207 & 81.9 & 0.8 & 9.6 & 9.6 & 0.3 & 2.3 & - \\
\hline Pears & 207 & 85.1 & 0.4 & 10.4 & 10.8 & 0.2 & 3 & 0.1 \\
\hline Apples & 207 & 85.3 & 0.3 & 11.3 & 11.3 & 0.2 & 1.9 & 0.5 \\
\hline Carrots & 138 & 89.4 & 0.8 & 4.9 & 6.6 & 0.3 & 2.2 & - \\
\hline Potatoes & 130 & 78.9 & 2 & 0.5 & 15.8 & 0.2 & 2.1 & - \\
\hline Tomatoes & 110 & 94.5 & 0.8 & 1.7 & 1.7 & 0.3 & 1.4 & 0.4 \\
\hline Total & 1000 & $85.2^{*}$ & $9 \mathrm{~g} \mathrm{~L}^{-1}$ & $86.7 \mathrm{~g} \mathrm{~L}^{-1}$ & $114 \mathrm{~g} \mathrm{~L}^{-1}$ & $2.7 \mathrm{~g} \mathrm{~L}^{-1}$ & $26.1 \mathrm{~g} \mathrm{~L}^{-1}$ & - \\
\hline
\end{tabular}

Represents the average of water content of the fruit and vegetable mixture (MFVW). 
Table 3

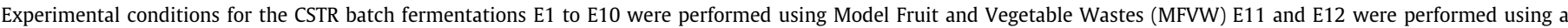
mixture of fruit and vegetable wastes (FVW) (+) with, (-) without.

\begin{tabular}{|c|c|c|c|c|c|c|c|c|}
\hline Experiment & Natural sea water (NSW) & $\mathrm{CaCl}_{2} \& \mathrm{MgCl}_{2}$ & Balch's oligo-elements & Yeast extract & $\mathrm{KH}_{2} \mathrm{PO}_{4} \& \mathrm{~K}_{2} \mathrm{HPO}_{4}$ & $\mathrm{Na}_{2} \mathrm{~S}$ & Cyst-HCl & $\mathrm{NH}_{4} \mathrm{Cl}$ \\
\hline E1 & - & + & + & + & + & + & + & + \\
\hline E2 & + & + & + & + & + & + & + & + \\
\hline E3 & + & - & - & + & + & + & + & + \\
\hline E4 & + & - & - & - & + & + & + & + \\
\hline E5 & + & - & - & - & - & + & + & + \\
\hline E6 & + & - & - & - & - & - & + & + \\
\hline E7 & + & - & - & - & - & + & - & + \\
\hline E8 & + & - & - & - & - & - & - & + \\
\hline E9 & + & - & - & - & - & + & - & - \\
\hline E10 & + & - & - & - & - & - & + & + \\
\hline E11 & + & - & - & - & - & - & + & + \\
\hline E12 & + & - & - & - & - & - & + & + \\
\hline
\end{tabular}

\subsection{Effects of natural seawater on growth and fermentative $H_{2}$ production of T. Maritima from MFVW}

T. maritima was grown in a mineral basal medium (MBM) with a concentration of MFVW equivalent to $41.6 \pm 2.2 \mathrm{mmol} \mathrm{L}^{-1}$ of total carbohydrates (experiment E1, Table 4). To reduce the production cost for $T$. maritima growth medium, natural seawater, a complex medium unlimitedly available and containing numerous minerals, was used for aqueous solution in a fermentation medium (NSM) (experiment E2, Table 3). The seawater used was directly harvested in the bay of Gammarth, Tunisia. Despite the advantages of seawater, the possible presence of heavy metals and/or hydrocarbons could inhibit microbial growth. There are few data available on the pollution of the coastal surface waters near Tunis. However, other studies have shown that samples collected from the Gulf of Gabès (south of the Gulf of Tunis) contain total dissolved aliphatic and polycyclic aromatic hydrocarbon concentrations ranging from 0.02 to $6.3 \mu \mathrm{g} \mathrm{L}^{-1}$ and from 8.9 to $197.8 \mathrm{ng} \mathrm{L}^{-1}$, respectively (Fourati et al., 2017). These results confirm that this area is moderate-to-highly impacted by hydrocarbons and such compounds can be found in the bay of Gammarth, and so might impact the growth of $T$. maritima. However, T. maritima grew in an equivalent manner in both MBM and NSM media in the presence of MFVW as carbon and energy sources (Figs. 2a and 2b, Table 4).

In experiments $\mathrm{E} 1$ and $\mathrm{E} 2,33.6 \mathrm{mmol} \mathrm{L}^{-1}$ of total carbohydrates $\left(42.4 \pm 0.8 \mathrm{mmol} \mathrm{L}^{-1}\right)$ was consumed. Both cultures reached maximum $\mathrm{H}_{2}$ productivity after approximately $6 \mathrm{~h}$ of fermentation. In these experiments, the maximum $\mathrm{H}_{2}$ production rates were about $12.4 \mathrm{mmol} \mathrm{h}^{-1} \mathrm{~L}^{-1}$, Table 4) showing the high potential of fermentative hydrogen production from fruit and vegetable wastes. Maximal hydrogen productivity of some Thermotoga strains has been reported to be between 2.7 and $14.5 \mathrm{mmol} \mathrm{h}^{-1} \mathrm{~L}^{-1}$ (Nguyen et al., 2008). Gomez-Romero et al. (2014) have obtained the highest overall productivity of biohydrogen $\left(2.16 \mathrm{~mm} \mathrm{~h}^{-1} \mathrm{H}_{2} \mathrm{~L}^{-1}\right)$ and the maximum volumetric $\mathrm{H}_{2}$ production rate $\left(10.6 \mathrm{mmol} \mathrm{h}^{-1}\right.$ $\mathrm{L}^{-1}$ ) when they combined fruit and vegetable wastes (FVW) with crude cheese whey (CCW) ( $\mathrm{C} / \mathrm{N}$ ratio of 21$)$. In the same way, Tenca et al. (2011) have obtained the highest production rate of $3.27 \pm 0.51 \mathrm{~L}_{\mathrm{H} 2} \mathrm{~L}^{-1} \mathrm{~d}^{-1}$ after using a mixture of fruit and vegetable wastes with swine manure with ratio of 35/65.

The consumption of soluble sugars was almost complete within $24 \mathrm{~h}$ with fast utilization of about $85 \%$ of the glucose and $50 \%$ of the fructose during the first $10 \mathrm{~h}$ (Fig. 2b). The consumption of both sugars corresponded to $74 \%$ of the total consumed sugars. The remainder consumed (26\%) corresponded to about $10 \pm 2 \mathrm{mmol}$ $\mathrm{L}^{-1}$ of complex carbohydrates, similar to the initial concentration of potato starch (11.8 $\mathrm{mmol} \mathrm{L}^{-1}$ ) in MFVW calculated from APRIFEL (2005) (Table 2). In our study, the growth rate of T. maritima could not be evaluated. However, recent studies showed that it depends on glucose, yeast extract, thiosulfate and dissolved hydrogen concentrations (Boileau et al., 2016; Auria et al., 2016).

T. maritima is known to metabolize both simple sugars and polysaccharides ranging from hexose and pentose monomers to starch and xylan polymers (Chhabra, 2003). The main fermentative end-products in both cases were essentially $\mathrm{H}_{2}$, acetate and $\mathrm{CO}_{2}$ with a little lactate production $\left(1.75 \pm 0.55 \mathrm{mmol} \mathrm{L}^{-1}\right.$, Table 4). The maximum $\mathrm{H}_{2}$ production was about $127.6 \pm 1.35 \mathrm{mmol} \mathrm{L}^{-1}$ equivalent to an average $\mathrm{H}_{2}$ yield on total consumed sugars of $3.8 \mathrm{~mol}$ of $\mathrm{H}_{2}$ per mole of total sugar, close to the theoretical $\mathrm{H}_{2}$ yield of $4 \mathrm{~mol}$ of $\mathrm{H}_{2}$ per mole of glucose in fermentation metabolism. Interestingly, total $\mathrm{H}_{2}$ production and $\mathrm{H}_{2}$ yield on consumed carbohydrates obtained in this study in $24 \mathrm{~h}$ were higher than those obtained with $T$. maritima cultured with optimal conditions (60 $\mathrm{mmol} \mathrm{L}^{-1}$ glucose, $1 \mathrm{~g} \mathrm{~L}^{-1}$ yeast extract and $0.12 \mathrm{mmol} \mathrm{L}^{-1}$ thiosulfate) (Boileau et al., 2016). These authors obtained, at the end of the fermentation ( $23 \mathrm{~h}$ of culture), a maximum total $\mathrm{H}_{2}$ production and $\mathrm{H}_{2}$ yield of about $99.7 \mathrm{mmol} \mathrm{L}^{-1}$ and $2.2 \mathrm{~mol} \mathrm{~mol}^{-1}$, respectively. However, compared with other hydrogen-producing microorganisms, T. maritima exhibited one of the highest $\mathrm{H}_{2}$ yields, close to the theoretical maximum value (Thauer limit) of $4 \mathrm{~mol}$ of $\mathrm{H}_{2}$ per mole of glucose (Cappelletti et al., 2012; Nguyen et al., 2008; Pradhan et al., 2015; Schröder et al., 1994). The hydrogen yield for Thermotoga neapolitana, with $10 \mathrm{~g} / \mathrm{L}$ sugars from carrot pulp hydrolysate, was about $2.7 \mathrm{~mol} \mathrm{H}_{2} \mathrm{~mol}^{-1}$ hexose (de Vrije et al., 2010). These authors have also shown that $T$. neapolitana did not grow when using carrot pulp in the bioreactor.

During fermentation of T. maritima on MFVW in the presence of NS, the only noteworthy difference was that the redox potential (Eh) of the culture medium was significantly lowered to about $-340 \mathrm{mV}$ and $-410 \mathrm{mV}$, respectively (Fig. 2b). Lakhal et al. (2011) showed that T. maritima was able to strongly reduce the redox potential of the culture medium, down to about $-480 \mathrm{mV}$, so long as glucose was available. The higher Eh measured in the presence of NS $(-340 \mathrm{mV})$ was probably due to oxidative compounds such as sulfate $\left(2.8 \mathrm{~g} \mathrm{~L}^{-1}\right)$ contained in NS. However, this higher Eh value did not affect the total $\mathrm{H}_{2}$ production (Fig. 2a).

\subsection{Effects of the different nutrients in natural seawater medium (NSM) on fermentative $\mathrm{H}_{2}$ production}

T. maritima was grown on NSM using MFVW as a source of nutrients and energy. Consistent with the origin of this hyperthermophilic bacterium isolated from hot submarine regions, the culture medium enabling its optimal growth is usually complex (Childers et al., 1992; Huber et al., 1986; Nguyen et al., 2008). To simplify this medium by using seawater and fruit and vegetable wastes, many experiments have been carried out following the protocol defined in Table 3, which lists the main components used 
Table 4

Results obtained for batch fermentations for experiments E1 to E12.

\begin{tabular}{|c|c|c|c|c|c|c|c|c|c|c|c|c|}
\hline Experiments & $\begin{array}{l}\text { E1 } \\
\text { MBM }\end{array}$ & $\begin{array}{l}\text { E2 } \\
\text { NSM }\end{array}$ & $\begin{array}{l}\text { E3 } \\
\text { E2 w/o oligo \& Ca/ } \\
\text { Mg }\end{array}$ & $\begin{array}{l}\text { E4 } \\
\text { E3 w/o } \\
\text { YE }\end{array}$ & $\begin{array}{l}\mathrm{E} 5 \\
\mathrm{E} 4 \mathrm{w} / \mathrm{o} \\
\mathrm{KPO}_{4}\end{array}$ & $\begin{array}{l}\text { E6 } \\
\text { E5 w/o } \\
\mathrm{Na}_{2} \mathrm{~S}\end{array}$ & $\begin{array}{l}\text { E7 } \\
\text { E5 w/o Cys- } \\
\mathrm{HCl}\end{array}$ & $\begin{array}{l}\text { E8 } \\
\text { E5 w/o Na } 2 \text { S \& Cys- } \\
\mathrm{HCl}\end{array}$ & $\begin{array}{l}\text { E9 } \\
\text { E6 w/o } \\
\mathrm{NH}_{4} \mathrm{Cl}\end{array}$ & $\begin{array}{l}\text { E10 } \\
\text { E6 + MFVW 2.6* } \\
\text { [sugars] }\end{array}$ & $\begin{array}{l}\text { E11 } \\
\text { E6 + } \\
\text { FVW }\end{array}$ & $\begin{array}{l}\mathrm{E}^{2} 2^{\mathrm{a}} \\
\text { E6 + FVW 3* } \\
\text { [sugars] }\end{array}$ \\
\hline Total carbohydrates $\left(\mathrm{mmol} \mathrm{L}^{-1}\right)$ & $\begin{array}{l}41.6 \pm \\
2.2\end{array}$ & $\begin{array}{l}43.2 \pm \\
1.6\end{array}$ & $42.8 \pm 2.1$ & $\begin{array}{l}45.9 \pm \\
1.8\end{array}$ & $48.1 \pm 1.9$ & $47.7 \pm 0.3$ & $49.7 \pm 3.2$ & $48.4 \pm 3.2$ & $42.4 \pm 1.8$ & $124.1 \pm 7.3$ & $\begin{array}{l}46.1 \pm \\
3.4\end{array}$ & $143 \pm 12.6$ \\
\hline Glucose $\left(\mathrm{mmol} \mathrm{L}^{-1}\right)$ & $\begin{array}{l}11.3 \pm \\
1.4\end{array}$ & $\begin{array}{l}12.4 \pm \\
0.9\end{array}$ & $13.9 \pm 1.4$ & $\begin{array}{l}14.8 \pm \\
2.1\end{array}$ & $15.7 \pm 3.2$ & $14.1 \pm 2.6$ & $16.5 \pm 2.7$ & $15.6 \pm 1.2$ & $12.6 \pm 1.1$ & $42.9 \pm 4.6$ & $\begin{array}{l}16.3 \pm \\
1.3\end{array}$ & $43.6 \pm 7.6$ \\
\hline Fructose $\left(\mathrm{mmol} \mathrm{L}^{-1}\right)$ & $\begin{array}{l}15.6 \pm \\
1.7\end{array}$ & $\begin{array}{l}17.6 \\
\pm 1.8\end{array}$ & $17.3 \pm 1.6$ & $\begin{array}{l}18.6 \pm \\
2.2\end{array}$ & $20.3 \pm 4.6$ & $20.3 \pm 3.9$ & $21.9 \pm 5.1$ & $18.9 \pm 2.8$ & $16.7 \pm 2.3$ & $52.9 \pm 5.3$ & $\begin{array}{l}19.2 \pm \\
2.6\end{array}$ & $50.6 \pm 8.7$ \\
\hline Others $(\operatorname{Starch} \ldots)\left(\mathrm{mmol} \mathrm{L}^{-1}\right)$ & 14.7 & 13.2 & 11.6 & 12.5 & 12.1 & 13.3 & 11.3 & 13.9 & 13.1 & 28.3 & 10.6 & 48.8 \\
\hline $\begin{array}{l}\text { Consumed carbohydrates } \\
\left(\mathrm{mmol} \mathrm{L}^{-1}\right)\end{array}$ & $\begin{array}{l}33.9 \pm \\
0.6\end{array}$ & $\begin{array}{l}33.2 \pm \\
0.3\end{array}$ & $34.5 \pm 1.3$ & $\begin{array}{l}33.9 \pm \\
0.5\end{array}$ & $33.6 \pm 0.5$ & $34.1 \pm 0.8$ & $37.2 \pm 0.9$ & $2.3 \pm 2$ & $1.2 \pm 0.8$ & $62.2 \pm 3.5$ & $\begin{array}{l}40.19 \pm \\
1.6\end{array}$ & $124.3 \pm 5.6$ \\
\hline Glucose $\left(\mathrm{mmol} \mathrm{L}^{-1}\right)$ & $\begin{array}{l}10.3 \pm \\
0.3\end{array}$ & $\begin{array}{l}11.5 \pm \\
0.5\end{array}$ & $13.2 \pm 0.7$ & $\begin{array}{l}13.3 \pm \\
1.2\end{array}$ & $14.5 \pm 1$ & $12.6 \pm 1.6$ & $15.6 \pm 0.3$ & $0.5 \pm 0.1$ & 0 & $20.4 \pm 1.5$ & $\begin{array}{l}15.7 \pm \\
0.6\end{array}$ & $37.2 \pm 2.3$ \\
\hline Fructose $\left(\mathrm{mmol} \mathrm{L}^{-1}\right)$ & $\begin{array}{l}11.5 \pm \\
0.7\end{array}$ & $\begin{array}{l}13.6 \pm \\
0.6\end{array}$ & $12.7 \pm 1.2$ & $\begin{array}{l}14.2 \pm \\
0.8\end{array}$ & $15 \pm 1.4$ & $15.6 \pm 0.8$ & $15.7 \pm 0.8$ & $1.6 \pm 0.2$ & 0 & $28.3 \pm 1.7$ & $\begin{array}{l}17.9 \pm \\
1.2\end{array}$ & $40.4 \pm 3.1$ \\
\hline Others $($ Starch $\ldots)\left(\mathrm{mmol} \mathrm{L}^{-1}\right)$ & 12.1 & 8.1 & 8.6 & 6.4 & 4.1 & 5.9 & 5.9 & 0.2 & 1.2 & 13.5 & 6.6 & 46.7 \\
\hline $\mathrm{H}_{2}$ total production $\left(\mathrm{mmol} \mathrm{L}^{-1}\right)$ & $\begin{array}{l}125 \pm \\
2.7\end{array}$ & $\begin{array}{l}129 \pm \\
2.9\end{array}$ & $122.7 \pm 3$ & $\begin{array}{l}120 \pm \\
2.5\end{array}$ & $109 \pm 1.9$ & $98 \pm 1.1$ & $86 \pm 1.6$ & $1.3 \pm 0.5$ & $0.3 \pm 0.1$ & $165 \pm 6.9$ & $\begin{array}{l}139 \pm \\
2.7\end{array}$ & $446 \pm 11.3$ \\
\hline $\mathrm{H}_{2}$ Yield $\left(\mathrm{mol} \mathrm{mol}^{-1}\right)$ & $\begin{array}{l}3.69 \pm \\
0.2\end{array}$ & $\begin{array}{l}3.89 \pm \\
0.05\end{array}$ & $3.56 \pm 0.1$ & $\begin{array}{l}3.54 \pm \\
0.2\end{array}$ & $3.24 \pm 0.1$ & $\begin{array}{l}2.87 \pm \\
0.05\end{array}$ & $2.31 \pm 0.1$ & $0.57 \pm 0.05$ & $0.25 \pm 0.2$ & $2.65 \pm 0.3$ & $\begin{array}{l}3.46 \pm \\
0.1\end{array}$ & $3.59 \pm 0.3$ \\
\hline $\begin{array}{l}\text { Maximal } \mathrm{H}_{2} \text { productivity (mmol } \\
\mathrm{h}^{-1} \mathrm{~L}^{-1} \text { ) }\end{array}$ & $\begin{array}{l}11.5 \pm \\
1.1\end{array}$ & $\begin{array}{l}12.4 \pm \\
1.8\end{array}$ & $8.8 \pm 0.8$ & $8.1 \pm 0.8$ & $7.3 \pm 1.3$ & $5.8 \pm 0.6$ & $5.6 \pm 0.8$ & 0 & 0 & $11.8 \pm 0.9$ & $\begin{array}{l}12.4 \pm \\
0.1\end{array}$ & $18.1 \pm 2.1$ \\
\hline Acetate production $\left(\mathrm{mmol} \mathrm{L}^{-1}\right)$ & $64 \pm 1.2$ & $65 \pm 1.4$ & $64 \pm 1.5$ & $61 \pm 1.2$ & $56 \pm 0.9$ & $50 \pm 0.6$ & $43.5 \pm 0.8$ & $1.6 \pm 0.2$ & $0.9 \pm 0.1$ & $96.8 \pm 3.2$ & $73 \pm 1.4$ & $226 \pm 5.1$ \\
\hline Lactate production $\left(\mathrm{mmol} \mathrm{L}^{-1}\right)$ & $\begin{array}{l}2.3 \pm \\
0.3\end{array}$ & $1.2 \pm 0.2$ & $4.3 \pm 1.2$ & $6.1 \pm 0.8$ & $10.1 \pm 1.1$ & $17.3 \pm 2.2$ & $29.3 \pm 3.6$ & $0.6 \pm 0.04$ & $0.9 \pm 0.05$ & $24.36 \pm 2.9$ & $6.4 \pm 1.2$ & $19.6 \pm 3.5$ \\
\hline $\begin{array}{l}\text { (lactate }+ \text { acetate }) / C_{\text {tot }}(\mathrm{mol} \\
\left.\mathrm{mol}^{-1}\right)\end{array}$ & 1.96 & 1.99 & 1.98 & 1.98 & 1.97 & 1.97 & 1.96 & 0.96 & 1.5 & 1.95 & 1.98 & 1.98 \\
\hline acetate $/ C_{\text {tot }}\left(\mathrm{mol} \mathrm{mol}^{-1}\right)$ & 1.88 & 1.96 & 1.86 & 1.8 & 1.67 & 1.47 & 1.17 & 0.70 & 0.75 & 1.56 & 1.82 & 1.82 \\
\hline $\mathrm{H}_{2} /$ acetate $\left(\mathrm{mol} \mathrm{mol}^{-1}\right)$ & 1.95 & 1.98 & 1.92 & 1.97 & 1.95 & 1.96 & 1.98 & 0.81 & 0.33 & 1.7 & 1.9 & 1.97 \\
\hline$\%$ of Consumed Sugars & 81.49 & 76.85 & 80.61 & 73.86 & 69.85 & 71.37 & 74.85 & 4.75 & 2.83 & 50.12 & 87.18 & 86.92 \\
\hline $\mathrm{CO}_{2}\left(\mathrm{mmol} \mathrm{L}^{-1}\right)$ & $\begin{array}{l}52.3 \pm \\
0.8\end{array}$ & $\begin{array}{l}53.6 \pm \\
1.1\end{array}$ & $51.1 \pm 1.9$ & $\begin{array}{l}54.2 \pm \\
2.1\end{array}$ & $49.3 \pm 1.8$ & $42 \pm 2.6$ & $39 \pm 2.3$ & $3.36 \pm 0.6$ & $2.23 \pm 0.2$ & $77.4 \pm 4.3$ & $\begin{array}{l}68.8 \pm \\
2.5\end{array}$ & $219 \pm 9.6$ \\
\hline $\mathrm{H}_{2} / \mathrm{CO}_{2}\left(\mathrm{~mol} \mathrm{~mol}^{-1}\right)$ & 2.39 & 2.41 & 2.4 & 2.21 & 2.21 & 2.33 & 2.21 & 0.39 & 0.13 & 2.13 & 2.02 & 2.04 \\
\hline
\end{tabular}

a After $43 \mathrm{~h}$ of fermentation. w/o: without. 


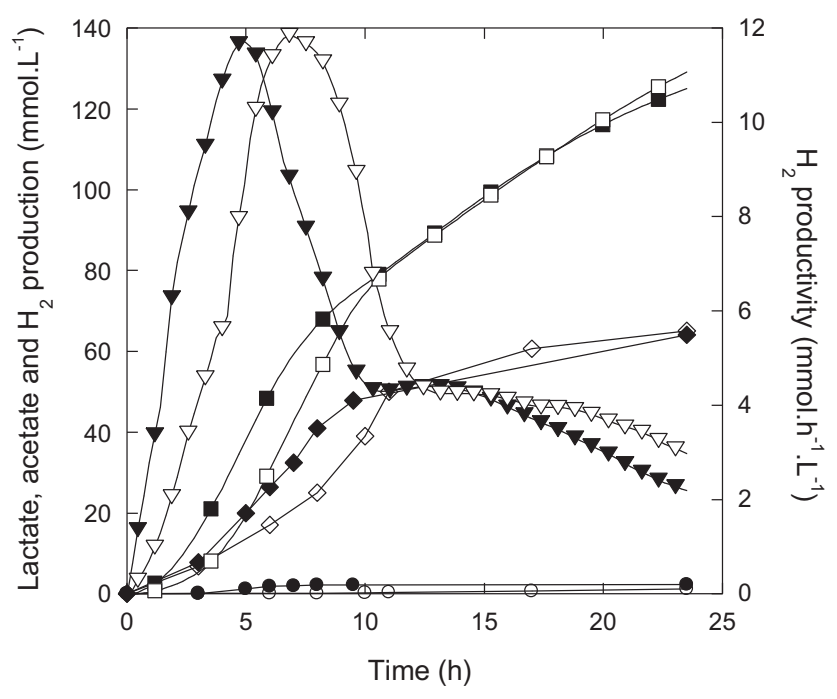

Fig. 2a. Lactate (E1: •, E2: O), acetate (E1: $\bullet, E 2: \diamond), \mathrm{H}_{2}$ production (E1: $\left.\mathbf{\square}, \mathrm{E} 2: \square\right)$ and $\mathrm{H}_{2}$ productivity (E1: $\left.\boldsymbol{\nabla}, \mathrm{E} 2: \nabla\right)$ versus time.

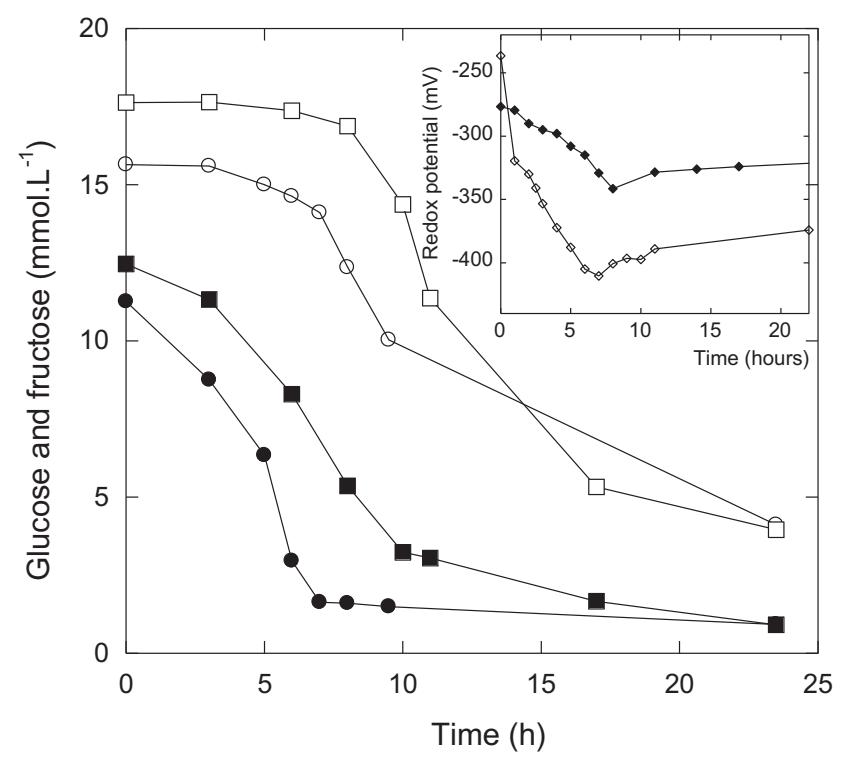

Fig. 2b. Glucose (E1: •, E2: $\mathbf{\square})$, fructose (E1: $\bigcirc, E 2: \square)$, and redox potential (E1: $\diamond$, E2: $\bullet$ ) versus time.

in the preparation of classic culture media (MBM) of T. maritima. Seawater contains oligo elements (Culkin, 1965) which can partially replace those contained in the classical culture medium of. T. maritima Each of these components was removed one by one from the culture medium (NSM) in order to evaluate their effects on total $\mathrm{H}_{2}$ volumetric production, consumed carbohydrates, $\mathrm{H}_{2}$ yield and average $\mathrm{H}_{2}$ productivity. The comparison of these experiments is summarized in Table 3.

In experiment $\mathrm{E} 3$, Balch's oligo-elements solution, $\mathrm{CaCl}_{2}$ and $\mathrm{MgCl}_{2}$ were removed from the culture medium. The results obtained (total $\mathrm{H}_{2}$ volumetric production, carbohydrates consumption and $\mathrm{H}_{2}$ yield) are listed in Table 4, and were similar to those of experiment E2. The highest $\mathrm{H}_{2}$ yield obtained (3.56 $\mathrm{mol} \mathrm{H}_{2} \mathrm{~mol}^{-1}$ total sugars) confirms that a large part of the sugars in MFVW was consumed for $\mathrm{H}_{2}, \mathrm{CO}_{2}$ and acetate production. The ability of T. maritima to grow without addition of these elements could be explained by their presence in both seawater and MFVW. Seawater contains calcium and magnesium at concentrations of about 0.41

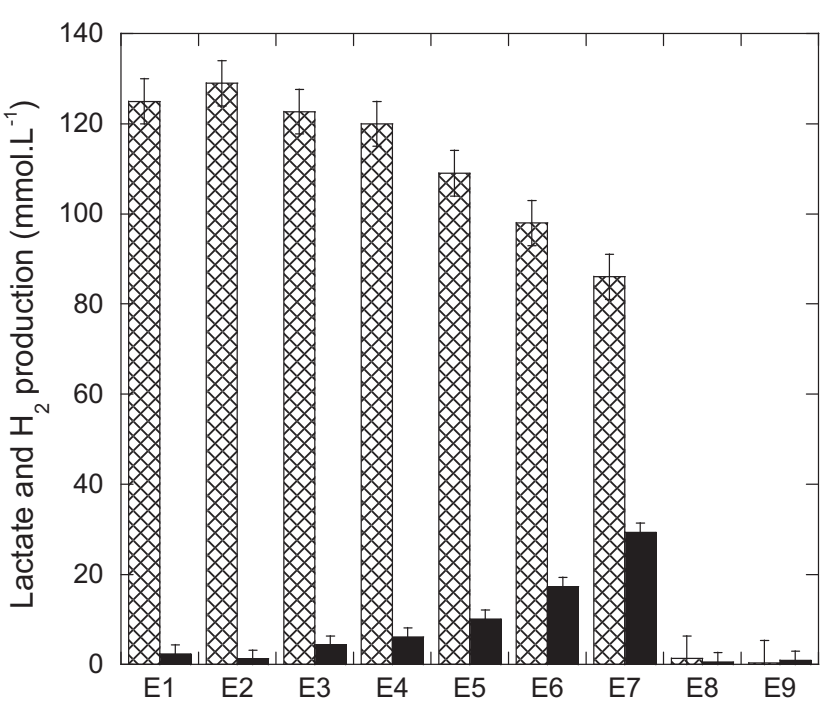

Fig. 3. Lactate ( $\square)$ and $\mathrm{H}_{2}$ production $(\otimes)$ at $24 \mathrm{~h}$ for the different experiments (E1 to E9).

and $1.29 \mathrm{~g} \mathrm{~L}^{-1}$, respectively (Culkin, 1965), higher than those present in $\operatorname{MBM}\left(\mathrm{CaCl}_{2} 0.1 \mathrm{~g} \mathrm{~L}^{-1}\right.$ and $\left.\mathrm{MgCl}_{2} 0.25 \mathrm{~g} \mathrm{~L}^{-1}\right)$.

In addition, MFVW contains many micro-elements ( $\mathrm{Mn}, \mathrm{Fe}, \mathrm{Zn}$, Co, etc.) normally provided by Balch's trace mineral elements added to MBM. Concentrations of $\mathrm{Mn}, \mathrm{Fe}, \mathrm{Zn}$, Co are about 0.07 , $0.2,0.15$ and $0.6 \mathrm{mg} \mathrm{L}^{-1}$, respectively (APRIFEL, 2005), above the corresponding concentrations in Balch's trace mineral elements solution. Though at low concentrations, the presence of these elements is essential for growth. They are necessary for the cellular transport processes, and act as enzyme cofactors (Gomez-Romero et al., 2014). For example, iron is a major constituent of bifurcating Fe-Fe hydrogenase in T. maritima, the key enzyme involved in fermentative hydrogen production, and containing a bimetallic $\mathrm{Fe}-\mathrm{Fe}$ active center (Schut et al., 2014). Its limitation can reduce biohydrogen production by deviating the fermentation pathways toward the production of more reduced end products such as lactate (Zhang and Shen, 2006). By contrast, it has been shown that supplementation of fermentative processes with $\mathrm{Fe}$ ion influences the system positively, and increases the fermentative hydrogen activity (Lee et al., 2001).

On the same basis as iron, the addition of tungsten to the growth medium of T. maritima increased both the cellular concentration of the Fe-Fe hydrogenase and it's in vitro activity. However, its function in the metabolism of this bacterium is still unknown: $T$. maritma can grow with or without added tungsten (Juszczak et al., 1991). However, tungsten is generally provided in the culture media via the oligo-element solution. In this experiment, Balch's oligo-element solution was removed from the medium, and its replacement by MFVW and seawater was not sufficient to obtain an optimal $\mathrm{H}_{2}$ production. This result could explain the small increase in lactate production (from $1.2 \mathrm{mmol} \mathrm{L}^{-1}$ to $4.3 \mathrm{mmol}$ $\mathrm{L}^{-1}$, Table 4, and Fig. 3 ) and the decrease maximum $\mathrm{H}_{2}$ productivity from $12.4 \mathrm{mmol} \mathrm{h}^{-1} \mathrm{~L}^{-1}$ to $8.8 \mathrm{mmol} \mathrm{h}^{-1} \mathrm{~L}^{-1}$ (Table 4).

In the next experiment (E4, Table 3 ), the yeast extract was removed from the culture medium (NSM). Compared with the previous experiment (E3), all the values of the fermentation process parameters remain unchanged (Fig. 3 and Table 4). Hence the absence of yeast extract does not affect the fermentation process of $T$. maritima, which produced a similar amount of hydrogen, $\mathrm{CO}_{2}$ and fermentative end-products (acetate and lactate) as in experiment E3. However, Boileau et al. (2016) showed that in the absence of yeast extract in batch fermentation with glucose as sole carbon and energy source, T. maritima growth was very weak, and 
biomass reached a limit of about $40 \mathrm{mg} \mathrm{L}^{-1}$. Furthermore, Maru et al. (2012) found that reducing the level of yeast extract affected negatively $\mathrm{H}_{2}$ production.

Other studies have obtained an improvement of biomass and $\mathrm{H}_{2}$ production after increasing yeast extract concentration from 1 to 4 $\mathrm{g} \mathrm{L}^{-1}$ in cultures on glycerol of $T$. neapolitana, a species very closely related to T. maritima (Ngo and Bui, 2013). The contribution of yeast extract to the growth of T. maritima is not yet clear, but it may play an important role in the fermentation process, providing nitrogen, mineral elements, amino acids and/or vitamins for bacterial growth. Rinker and Kelly (2000) showed that T. maritima did not significantly consume individual amino acids added to culture media. However, d'Ippolito et al. (2010) reported that consumption of protein sources (peptone, tryptone and yeast extract) accounts for $10-15 \%$ of the total $\mathrm{H}_{2}$ production by $T$. neapolitana. Interestingly, most of the amino acids present in the yeast extract, such as lysine, phenylalanine, leucine, valine, methionine, cystine, tryptophan, threonine, isoleucine, aspartic acid and proline were also present in our model fruit and vegetable wastes (http://www.whfoods.com/). Moreover, these concentrations were higher than or similar to those added to the medium by yeast extract $\left(1 \mathrm{~g} \mathrm{~L}^{-1}\right)$. With regard to vitamins present in yeast extract, Childers et al. (1992) showed that only biotin was required for optimal growth of Thermotoga maritima. However, we underline that vitamins of yeast extract can be replaced by those contained in MFV, such as vitamin $\mathrm{A}, \mathrm{B}, \mathrm{C}$ and $\mathrm{E}$, with average concentrations of around $0.25,2,4$ and $0.37 \mathrm{mg} \mathrm{L}^{-1}$, respectively (APRIFEL, 2005). Hence, in our study, it is clearly shown that seawater and fruit and vegetable wastes contain enough minerals and nutrient substances (peptides, amino acids and vitamins) to effectively replace the yeast extract of the classic medium (MBM). Ljunggren and Zacchi (2009) demonstrated that yeast extract was the main cost contributor during different hydrogen fermentation strategies (high $\mathrm{H}_{2}$ productivity and high $\mathrm{H}_{2}$ yield) which accounted for $49 \%$ and $93 \%$ of the nutrient cost, respectively.

Experiment E5 (Table 3) consisted in removing $\mathrm{KH}_{2} \mathrm{PO}_{4}$ and $\mathrm{K}_{2} \mathrm{HPO}_{4}$, considered as potassium and phosphate inorganic sources, from the culture medium (NSM). Compared with the previous experiment (E4), all the values of parameters describing the fermentation process (E5) such as total hydrogen production (Fig. 3), acetate and $\mathrm{CO}_{2}$ production, $\mathrm{H}_{2}$ productivities and yield $\mathrm{H}_{2} / \mathrm{C}_{\text {tot }}$ (Table 4 ) were slightly decreased against an increase in lactate production (Fig. 3, Table 4). Potassium was supplied by the seawater $(0.4 \mathrm{~g}$ $\left.\mathrm{L}^{-1}\right)$, but phosphate was present at a low concentration. Phosphate is considered as an important inorganic nutrient for microbial growth and for optimal $\mathrm{H}_{2}$ production (Liu et al., 2015). In our experiment, the decrease in the values of total hydrogen production, acetate and $\mathrm{CO}_{2}$ production (Table 4) showed that the low phosphate supply was sufficient to enable the growth of T. maritima. However, we observed an increase in lactate production (Fig. 3) and a corresponding small decrease in $\mathrm{H}_{2}$ productivity (Table 4), which demonstrates a slight orientation of the metabolism toward lactate production. Besides its function as a macro-element (phosphorus), phosphate can also increase $\mathrm{H}_{2}$ production when it reacts with calcium (Liu et al., 2015). Chang and Lin (2006) have shown that an overly-high calcium concentration $\left(0.3 \mathrm{~g} \mathrm{~L}^{-1}\right)$ with small phosphate concentrations can decrease $\mathrm{H}_{2}$ productivity. In our experiment $\mathrm{E} 5$, the natural seawater provided $0.41 \mathrm{~g} \mathrm{~L}^{-1}$ of $\mathrm{CaCl}_{2}$, which might explain the slight fall in $\mathrm{H}_{2}$ productivity in the absence of phosphate. However, some other studies have found that excess amounts of phosphate can increase the production of volatile fatty acids, which is not desirable as this diverts the cellular reductants away from hydrogen production (Chandrasekhar et al., 2015).

Experiments E6 and E7 each eliminated one of the two sulfur compounds $\left(\mathrm{Na}_{2} \mathrm{~S}\right.$ for $\mathrm{E} 6$ and cysteine- $\mathrm{HCl}$ for $\left.\mathrm{E} 7\right)$ from the culture medium specified for experiment E5 (Table 3). The absence of one of these sulfur compounds decreased total $\mathrm{H}_{2}$ production (Fig. 3) concomitant with a decrease in $\mathrm{H}_{2}$ productivity and yield $\mathrm{H}_{2} / \mathrm{C}_{\text {tot }}$ for the two experiments (Table 4). Furthermore, lactate production was increased to $29.3 \mathrm{mmol} \mathrm{L}^{-1}$ for E7. Sulfur compounds under different forms (elemental sulfur, cysteine, $\mathrm{Na}_{2} \mathrm{~S}$, thiosulfate, etc.) are essential for T. maritima growth and they can be used as an electron acceptor to remove the inhibition due to a high partial hydrogen pressure (Huber and Harning, 2006; Schröder et al., 1994; Ravot et al., 1995; Childers et al., 1992). Moreover, Boileau et al. (2016) have shown that adding thiosulfate at low concentrations $\left(0.12 \mathrm{mmol} \mathrm{L}^{-1}\right)$ is sufficient to allow an optimum growth of this bacterium with a significant increase in hydrogen production. However, in our case, the significant input of sulfur compounds $\left(\mathrm{Na}_{2} \mathrm{~S} 5.12 \mathrm{mmol} \mathrm{L}^{-1}\right.$ or cysteine- $\left.\mathrm{HCl} 1.9 \mathrm{mmol} \mathrm{L}^{-1}\right)$ led to a significant reduction in growth parameter values of $T$. maritima. This negative effect may be explained by the oxidation of some $\mathrm{Na}_{2} \mathrm{~S}$ or cysteine- $\mathrm{HCl}$ by the oxygen introduced into the anoxic medium after adding MFVW, stored under aerobic conditions.

The oxidation of sulfur compounds could thus reduce the available sulfur concentration needed for T. maritima growth. Sulfur compounds are essential for protein, Fe-S clusters and ferredoxin synthesis. The low sulfur concentration with $\mathrm{Na}_{2} \mathrm{~S}$ addition in experiment E7 could result in priority being given to the protein synthesis rather than the Fe-S cluster formation (Ainala et al., 2016). This case could explain the strong increase in lactate production, since there is a limitation in T. maritima's Fe-Fe hydrogenase synthesis. Besides, we note that seawater does not contain the sulfur compounds necessary for T. maritima growth. Experiment E8 (Table 3) showed that removing all sulfur compounds inhibits T. maritima growth, even in the presence of the sulfurcontaining amino acids (methionine and oxidized cysteine) provided by MFVW (Table 4, Figs. 2a and $2 b$ ).

Experiment 9 (E9) involved removing the nitrogen source $\left(\mathrm{NH}_{4}-\right.$ $\mathrm{Cl}$ ) from the culture medium specified for experiment E7 (Table 3). Rinker and Kelly (2000) showed that $\mathrm{NH}_{4} \mathrm{Cl}$ and not amino acids serves as a nitrogen source for T. maritima, and no growth of this bacterium was found in the absence of this element. They also showed that increasing $\mathrm{NH}_{4} \mathrm{Cl}$ concentrations up to $1.0 \mathrm{~g} \mathrm{~L}^{-1}$ in continuous culture stimulated biomass yields for $T$. maritima. In our study, MFVW and natural seawater did not contain inorganic nitrogen sources. Thus T. maritima did not grow without addition of this element.

From these different experiments, we specified a minimal culture medium containing natural seawater, fruit and vegetable wastes supplemented with cysteine- $\mathrm{HCl}$ and inorganic nitrogen source $\left(\mathrm{NH}_{4} \mathrm{Cl}\right)$ (based on experiment E6). This simplified culture medium was then used as a base medium for testing different sugar concentrations, and the ability of T. maritima to produce $\mathrm{H}_{2}$ from a mixture of fruit and vegetable waste (FVW) directly harvested from a landfill.

\subsection{Effects of using FVW and higher sugar concentrations on fermentative $\mathrm{H}_{2}$ production}

After specifying a simplified culture medium (E6) and studying the growth of T. maritima in the presence of MFVW, the capacity of this bacterium to grow and produce $\mathrm{H}_{2}$ from fruit and vegetable waste (FVW) was evaluated (E11). FVW was a mixture of fruit and vegetable waste collected from a wholesale market landfill (Bir Kassa, Tunis). The sampling was performed during the winter period, when the waste was composed of different quantities of apples, carrots, potatoes, tomatoes, pears, onions, fennel, spinach, parsley and citrus fruits (oranges and tangerines). Many studies have shown a decrease in $\mathrm{H}_{2}$ production related to the presence of flavor compounds in citrus fruit (esters, alcohols, aldehydes, ketones, lactones and terpenoids), which inhibit the growth of 
many microorganisms (Akinbomi and Taherzadeh, 2015). For instance, d-limonene (a citrus flavor belonging to a class of terpenoids) was found to have an antimicrobial effect at a very low concentration of $0.01 \% \mathrm{w} / \mathrm{v}$ (Mizuki et al., 1990). It can also cause the failure of the anaerobic digestion process, even at a very low concentration of $400 \mu \mathrm{L} \mathrm{L}^{-1}$ (Mizuki et al., 1990). However, in our study, the presence in FVW of citrus fruits (oranges and tangerines) did not affect $\mathrm{H}_{2}$ production by $T$. maritima. On the contrary, $\mathrm{H}_{2}$ production was promoted despite their presence (Fig. 4 and Table 4).

To compare with experiment E6, E11 was performed with an equivalent total carbohydrate concentration of about $46.1 \mathrm{mmol}$ $\mathrm{L}^{-1}$. Contrary to E6 and in $24 \mathrm{~h}$ of fermentation, FVW significantly improved the total hydrogen volumetric production (Table 4 and Fig. 4). Many factors related to the composition of FVW (rheological characterization, biodegradability of carbohydrates, mineral elements, etc.) could be responsible for increasing $\mathrm{H}_{2}$ production. Nevertheless, the results obtained from E11 were similar to those obtained in experiments E1 and E2, which used the complete composition of MBM necessary for optimum growth. This increase is consistent with the consumption of total carbohydrates (essentially simple sugars) which was about $90 \%$. This higher consumption could be explained by the microbial hydrolysis of complex carbohydrates during their landfilling. Furthermore, the fermentation with FVW allowed an increase in the maximum $\mathrm{H}_{2}$ productivity up to $12.4 \mathrm{mmol} \mathrm{h}^{-1} \mathrm{~L}^{-1}$ (Fig. 4) similar to that obtained in experiment E2 with the complete medium (MBM) $(12.4 \mathrm{mmol}$ $\mathrm{h}^{-1} \mathrm{~L}^{-1}$, Table 4). Hence the heterogeneous FVW composition is able to replace the different mineral compounds removed in NSM (E6). One example is the presence in FVW of onions rich in organosulfur compounds, which can replace the removed sulfur necessary for T. maritima growth (Ueda et al., 1994). In addition, onions are composed of many nutrients such as phosphorus, potassium and sulfur, with corresponding concentrations of about 193, 822 and $282 \mathrm{mg} \mathrm{L}^{-1}$, respectively (Romano and Zhang, 2008). It was observed that adding $1 \%$ onion storage wastes to cattle dung in a bioreactor increased biogas production by $40-80 \%$ (Yadvika et al., 2004). The elements could therefore be easily assimilated by $T$. maritima.

The effect of MFVW and FVW concentrations on the production of $\mathrm{H}_{2}$ was assessed using the simplified culture medium (NSM). The two initial equivalent C6 concentrations from MFVW and FVW were multiplied by about $2.8 \pm 0.2\left(124.1 \mathrm{mmol} \mathrm{L}^{-1}\right.$ for E10

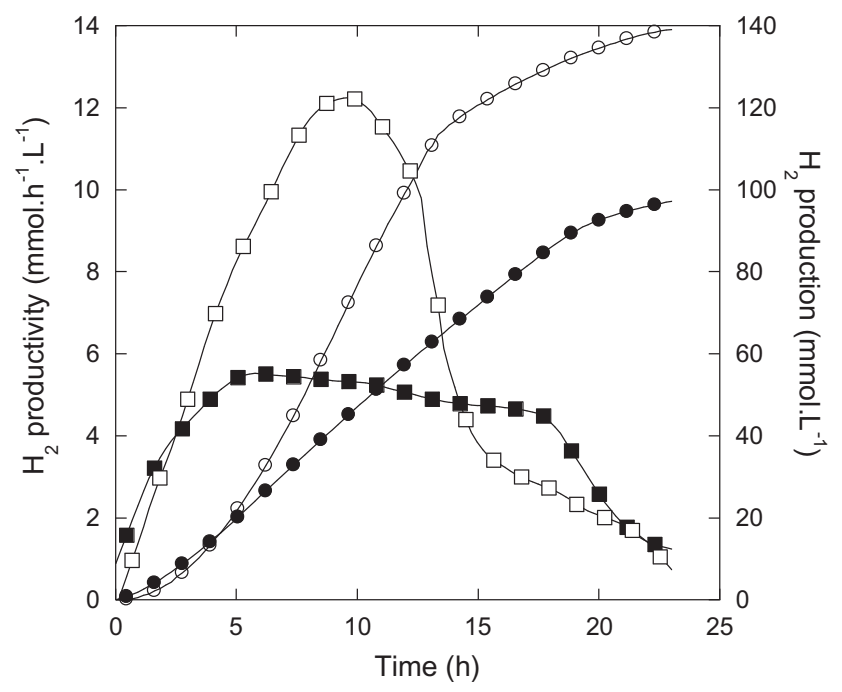

Fig. 4. $\mathrm{H}_{2}$ productivity (E6: $\square$, E11: $\square$ ) and $\mathrm{H}_{2}$ production (E6: •, E11: $\mathrm{O}$ ) versus time.

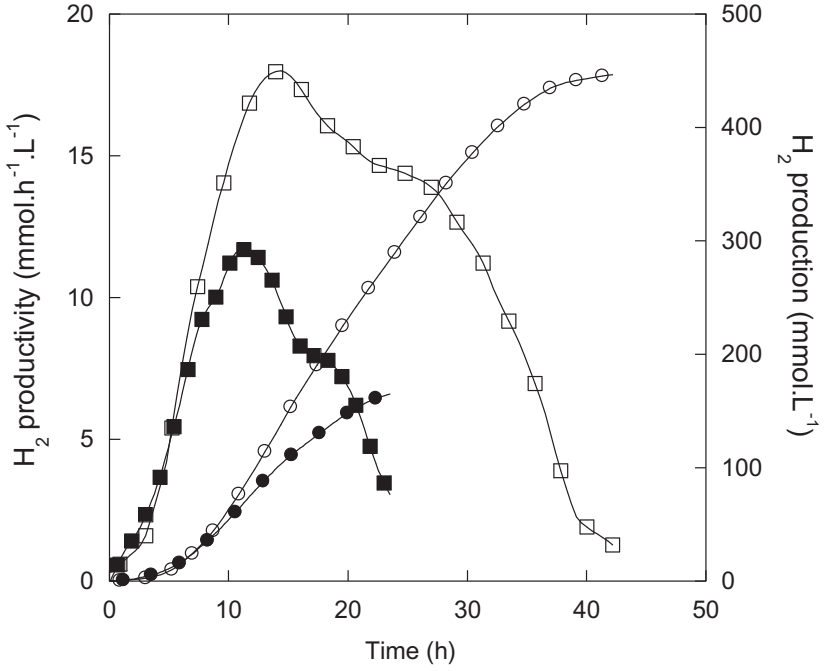

Fig. 5. $\mathrm{H}_{2}$ productivity (E10:ם, E12: $\square$ ) and $\mathrm{H}_{2}$ production (E10: ๑, E12: $\bigcirc$ ) versus time.

and $143 \mathrm{mmol} \mathrm{L}^{-1}$ for E12) compared with experiments E6 and E11 (47.7 and $46.1 \mathrm{mmol} \mathrm{L}^{-1}$ respectively) (Table 4 ). The difference between the two experiments was noteworthy by the duration of fermentation, which was $24 \mathrm{~h}$ for E10 and $43.5 \mathrm{~h}$ for E12. In experiment E10, the fermentation was finished after $24 \mathrm{~h}$ with total carbohydrate consumption around $62.2 \pm 3.5 \mathrm{mmol} \mathrm{L}^{-1}$ (Table 4 ). However, there was an increase in $\mathrm{H}_{2}$ productivity $(11.8 \mathrm{mmol}$ $\left.\mathrm{h}^{-1} \mathrm{~L}^{-1}\right)$ in comparison with experiment E6 $\left(5.8 \mathrm{mmol} \mathrm{h}^{-1} \mathrm{~L}^{-1}\right)$ (Table 4). Thus, the addition of MFVW provided some elements that improved the consumption of total sugars and $\mathrm{H}_{2}$ production, but still not enough to allow the consumption of total carbohydrates by T. maritima. However, unlike experiment E10 performed with MFVW, culture conditions in experiment E12 (with FVW), allowed the fermentation of a significant part of the carbohydrates (87\%) in $43.5 \mathrm{~h}$ of culture (Table 4 ).

Furthermore, in our study, the maximum $\mathrm{H}_{2}$ productivity obtained in $\mathrm{E} 12$ increased to $18.6 \mathrm{mmol} \mathrm{h}^{-1} \mathrm{~L}^{-1}$ (Fig. 5). This value was previously obtained only when $T$. maritima was cultivated on $4 \mathrm{~g} \mathrm{~L}^{-1}$ of yeast extract and $60 \mathrm{mmol} \mathrm{L}^{-1}$ of glucose (Boileau et al., 2016). Interestingly, the decrease in $\mathrm{H}_{2}$ production rates seems to be explained by the consumption of most of the total carbohydrates, contrary to experiment E10. Hence FVW supplies all the compounds necessary for an optimal $T$. maritima growth such as organosulfur compounds and pre-hydrolysis complex carbohydrates. Moreover, in our culture conditions (high temperature and anaerobic conditions), FVW has other advantages. Indeed, the lysis of the microflora present within the waste provided usable compounds such as vitamins, amino acids, micro and macro-elements. In conclusion, $T$. maritima produced the equivalent of $446 \mathrm{mmol} \mathrm{L}^{-1}$ of $\mathrm{H}_{2}$ (Fig. 5) in E12 in the presence of FVW, supplemented only with $\mathrm{NH}_{4} \mathrm{Cl}$ as a nitrogen source, and cysteine $\mathrm{HCl}$ as a sulfur source.

\section{Conclusion}

This study demonstrates that the supply of seawater in fermentative $\mathrm{H}_{2}$ production from fruit and vegetable wastes can replace certain nutrients necessary in mineral basal medium (MBM), and without modifying the total $\mathrm{H}_{2}$ production. On the other hand, it is agreed from this work that the absence of a source of nitrogen and sulfur prevented $\mathrm{H}_{2}$ production by $T$. maritima. Thus, the batch fermentation carried out in a culture medium containing organic market wastes and seawater appears as an alternative in the $\mathrm{H}_{2}$ 
production. Such methods of $\mathrm{H}_{2}$ production will encourage reducing the process-associated cost by simplifying the culture medium of hydrogen-forming bacteria.

\section{Acknowledgements}

Authors gratefully acknowledge the National Institute of Applied Sciences and Technology (INSAT, Tunisia), the Ministry of Higher Education and Scientific Research in Tunisia and the French Research Institute for Development (IRD) through the young associated team Biotec $\mathrm{H}_{2}$ for their supports.

\section{References}

Ainala, S.K., Seol, E., Kim, J.R., Park, S., 2016. Effect of culture medium on fermentative and CO-dependent $\mathrm{H} 2$ production activity in Citrobacter amalonaticus Y19. Int. J. Hydrog. Energy 41, 6734-6742. https://doi.org/ 10.1016/j.ijhydene.2016.03.088.

Akinbomi, J., Taherzadeh, M.J., 2015. Evaluation of Fermentative Hydrogen Production from Single and Mixed Fruit Wastes. Energies 8, 4253-4272. https://doi.org/10.3390/en8054253.

American Public Health Association, American Water Works Association, Water 2005. Standard methods for the examination of water and wastewater. APHA Wash. USA

ANGED, 2016. Anged - Quantités et types de déchets ménagers et assimilés [WWW Document]. Agence Natl. Gest. Déchets. URL http://www.anged.nat.tn/index. php? option=com_content\&view $=$ article\&id $=153 \&$ Itemid=203 (accessed 12.15.16).

Argun, H., Gokfiliz, P., Karapinar, I., 2017. Biohydrogen Production Potential of Different Biomass Sources. In: Singh, A., Rathore, D. (Eds.), Biohydrogen Production: Sustainability of Current Technology and Future Perspective. Springer India, New Delhi, pp. 11-48.

Auria, R., Boileau, C., Davidson, S., Casalot, L., Christen, P., Liebgott, P.P., CombetBlanc, Y., 2016. Hydrogen production by the hyperthermophilic bacterium Thermotoga maritima Part II: modeling and experimental approaches for hydrogen production. Biotechnol. Biofuels 9, 268. https://doi.org/10.1186/ s13068-016-0681-0.

Boileau, C., Auria, R., Davidson, S., Casalot, L., Christen, P., Liebgott, P.-P., CombetBlanc, Y., 2016. Hydrogen production by the hyperthermophilic bacterium Thermotoga maritima part I: effects of sulfured nutriments, with thiosulfate as model, on hydrogen production and growth. Biotechnol. Biofuels 9. https://doi. org/10.1186/s13068-016-0678-8.

Bouallagui, H., Lahdheb, H., Ben Romdan, E., Rachdi, B., Hamdi, M., 2009. Improvement of fruit and vegetable waste anaerobic digestion performance and stability with co-substrates addition. J. Environ. Manage. 90, 1844-1849. https://doi.org/10.1016/j.jenvman.2008.12.002.

Bouallagui, H., Touhami, Y., Ben Cheikh, R., Hamdi, M., 2005. Bioreactor performance in anaerobic digestion of fruit and vegetable wastes. Process Biochem. 40, 989995. https://doi.org/10.1016/j.procbio.2004.03.007.

Cappelletti, M., Bucchi, G., De Sousa Mendes, J., Alberini, A., Fedi, S., Bertin, L. Frascari, D., 2012. Biohydrogen production from glucose, molasses and cheese whey by suspended and attached cells of four hyperthermophilic Thermotoga strains. J. Chem. Technol. Biotechnol. 87, 1291-1301. https://doi.org/10.1002/ jctb.3782.

Cardoso, V., Romão, B.B., Silva, F.T., Santos, J.G., Batista, F.R., Ferreira, J.S., 2014 Hydrogen production by dark fermentation. Chem. Eng. Trans. 38, 481-486.

Chandrasekhar, K., Lee, Y.-J., Lee, D.-W., 2015. Biohydrogen production: strategies to improve process efficiency through microbial routes. Int. J. Mol. Sci. 16, 8266 8293. https://doi.org/10.3390/ijms16048266.

Chang, F.-Y., Lin, C.-Y., 2006. Calcium effect on fermentative hydrogen production in an anaerobic up-flow sludge blanket system. Water Sci. Technol. 54, 105. https://doi.org/10.2166/wst.2006.867.

Chhabra, S.R., 2003. Carbohydrate-induced differential gene expression patterns in the hyperthermophilic bacterium Thermotoga maritima. J. Biol. Chem. 278, 7540-7552. https://doi.org/10.1074/jbc.M211748200.

Childers, S.E., Vargas, M., Noll, K.M., 1992. Improved methods for cultivation of the extremely thermophilic bacterium Thermotoga neapolitana. Appl. Environ. Microbiol. 58, 3949-3953.

Culkin F, 1965. The major constituents of seawater. In: Riley, J.P., Skirrow, G. (Eds.) Chemical Oceanography, first ed. Academic Press, Recherche Google [WWW Document], pp. 121-161 (accessed 5.22.17).

d'Ippolito, G., Dipasquale, L., Vella, F.M., Romano, I., Gambacorta, A., Cutignano, A., Fontana, A., 2010. Hydrogen metabolism in the extreme thermophile Thermotoga neapolitana. Int. J. Hydrog. Energy 35, 2290-2295. https://doi.org/ 10.1016/j.ijhydene.2009.12.044.

Das, D., Khanna, N., Dasgupta, C.N., 2014. Biohydrogen Production: Fundamentals and Technology Advances. CRC Press.

De Gioannis, G., Muntoni, A., Polettini, A., Pomi, R., 2013. A review of dark fermentative hydrogen production from biodegradable municipal waste fractions. Waste Manage. 33, 1345-1361. https://doi.org/10.1016/j. wasman.2013.02.019. de Vrije, T., Bakker, R.R., Budde, M.A., Lai, M.H., Mars, A.E., Claassen, P.A., 2009. Efficient hydrogen production from the lignocellulosic energy crop Miscanthus by the extreme thermophilic bacteria Caldicellulosiruptor saccharolyticus and Thermotoga neapolitana. Biotechnol. Biofuels 2, 12. https://doi.org/10.1186/ 1754-6834-2-12.

de Vrije, T., Budde, M.A.W., Lips, S.J., Bakker, R.R., Mars, A.E., Claassen, P.A.M., 2010. Hydrogen production from carrot pulp by the extreme thermophiles Caldicellulosiruptor saccharolyticus and Thermotoga neapolitana. Int. J. Hydrog. Energy, 3rd Asian Bio Hydrogen Symposium 35, 13206-13213. https://doi.org/10.1016/j.ijhydene.2010.09.014.

Fourati, R., Tedetti, M., Guigue, C., Goutx, M., Garcia, N., Zaghden, H., Sayadi, S., Elleuch, B., 2017. Sources and spatial distribution of dissolved aliphatic and polycyclic aromatic hydrocarbons in surface coastal waters of the Gulf of Gabès (Tunisia, Southern Mediterranean Sea). Prog. Oceanogr. doi:10.1016/j. pocean.2017.02.001.

Garcia-Peña, E.I., Parameswaran, P., Kang, D.W., Canul-Chan, M., Krajmalnik-Brown, R., 2011. Anaerobic digestion and co-digestion processes of vegetable and fruit residues: process and microbial ecology. Bioresour. Technol. 102, 9447-9455. https://doi.org/10.1016/j.biortech.2011.07.068.

Gomez-Romero, J., Gonzalez-Garcia, A., Chairez, I., Torres, L., García-Peña, E.I., 2014. Selective adaptation of an anaerobic microbial community: biohydrogen production by co-digestion of cheese whey and vegetables fruit waste. Int. J. Hydrog. Energy 39, 12541-12550. https://doi.org/10.1016/j.ijhydene.2014.06.050.

Guo, X.M., Trably, E., Latrille, E., Carrère, H., Steyer, J.-P., 2010. Hydrogen production from agricultural waste by dark fermentation: a review. Int. J. Hydrog. Energy 35, 10660-10673. https://doi.org/10.1016/j.ijhydene.2010.03.008.

Huber, R., Hannig, M., 2006. Thermotogales. In: Dworkin, M., Falkow, S., Rosenberg, E., Schleifer, K.-.H., Stackebrandt, E. (Eds.), The Prokaryotes. Springer, New York, New York, NY, pp. 899-922.

Huber, R., Langworthy, T.A., König, H., Thomm, M., Woese, C.R., Sleytr, U.B., Stetter, K.O., 1986. Thermotoga maritima sp. nov. represents a new genus of unique extremely thermophilic eubacteria growing up to 90 C. Arch. Microbiol. 144 324-333.

James, C.S., 2013. Analytical Chemistry of Foods. Springer Science \& Business Media.

Juszczak, A., Aono, S., Adams, M.W., 1991. The extremely thermophilic eubacterium, Thermotoga maritima, contains a novel iron-hydrogenase whose cellular activity is dependent upon tungsten. J. Biol. Chem. 266, 13834-13841.

Kanchanasutaa, S., Haosagul, S., Pisutpaisal, N., 2016. Metabolic flux analysis of hydrogen production from rice starch by anaerobic sludge under varying organic loading. Chem. Eng. 49.

Lakhal, R., Auria, R., Davidson, S., Ollivier, B., Durand, M.-C., Dolla, A., Hamdi, M., Combet-Blanc, Y., 2011. Oxygen uptake rates in the hyperthermophilic anaerobe Thermotoga maritima grown in a bioreactor under controlled oxygen exposure: clues to its defence strategy against oxidative stress. Arch. Microbiol. 193, 429-438. https://doi.org/10.1007/s00203-011-0687-8.

Lee, Y.J., Miyahara, T., Noike, T., 2001. Effect of iron concentration on hydrogen fermentation. Bioresour. Technol. 80, 227-231.

Leema, J.T.M., Kirubagaran, R., Vinithkumar, N.V., Dheenan, P.S., Karthikayulu, S., 2010. High value pigment production from Arthrospira (Spirulina) platensis cultured in seawater. Bioresour. Technol. 101, 9221-9227. https://doi.org/ 10.1016/j.biortech.2010.06.120.

Liu, Q., Chen, W., Zhang, X., Yu, L., Zhou, J., Xu, Y., Qian, G., 2015. Phosphate enhancing fermentative hydrogen production from substrate with municipal solid waste composting leachate as a nutrient. Bioresour. Technol. 190, 431437. https://doi.org/10.1016/j.biortech.2015.01.139.

Ljunggren, M., Zacchi, G., 2009. Techno-economic evaluation of a two-step biological process for hydrogen production. Biotechnol. Prog. NA-NA. doi:10.1002/btpr.336.

Marone, A., Izzo, G., Mentuccia, L., Massini, G., Paganin, P., Rosa, S., Varrone, C., Signorini, A., 2014. Vegetable waste as substrate and source of suitable microflora for bio-hydrogen production. Renew. Energy 68, 6-13. https://doi. org/10.1016/j.renene.2014.01.013.

Maru, B.T., Bielen, A.A.M., Kengen, S.W.M., Constantí, M., Medina, F., 2012. Biohydrogen production from glycerol using Thermotoga spp. Energy Proc. 29, 300-307. https://doi.org/10.1016/j.egypro.2012.09.036.

Mason, J., Zweibel, K., 2007. Baseline model of a centralized pv electrolytic hydrogen system. Int. J. Hydrog. Energy 32, 2743-2763. https://doi.org/10.1016/j. ijhydene.2006.12.019.

Mizuki, E., Akao, T., Saruwatari, T., 1990. Inhibitory effect of Citrus unshu peel on anaerobic digestion. Biol. Wastes 33, 161-168. https://doi.org/10.1016/02697483(90)90002-A.

Mohan, S.V., 2010. Waste to renewable energy: a sustainable and green approach towards production of biohydrogen by acidogenic fermentation. In: Singh, O.V., Harvey, S.P. (Eds.), Sustainable Biotechnology. Springer, Netherlands, Dordrecht, pp. $129-164$.

Ngo, T.A., Bui, H.T.V., 2013. Biohydrogen production using immobilized cells of hyperthermophilic eubacterium Thermotoga neapolitana on porous glass beads. J. Technol. Innov. Renew. Energy 2, 231.

Nguyen, T., Pyokim, J., Sunkim, M., Kwanoh, Y., Sim, S., 2008. Optimization of hydrogen production by hyperthermophilic eubacteria, Thermotoga maritima and Thermotoga neapolitana in batch fermentation. Int. J. Hydrog. Energy 33, 1483-1488. https://doi.org/10.1016/j.ijhydene.2007.09.033.

Pathak, V.V., Ahmad, S., Pandey, A., Tyagi, V.V., Buddhi, D., Kothari, R., 2016. Deployment of fermentative biohydrogen production for sustainable economy in Indian scenario: practical and policy barriers with recent progresses. Curr. Sustain. Energy Rep. 3, 101-107. https://doi.org/10.1007/s40518-016-0052-2. 
Pradhan, N., Dipasquale, L., d'Ippolito, G., Panico, A., Lens, P., Esposito, G., Fontana, A., 2015. Hydrogen production by the thermophilic bacterium Thermotoga neapolitana. Int. J. Mol. Sci. 16, 12578-12600. https://doi.org/10.3390/ ijms160612578.

Ramírez-Morales, J.E., Tapia-Venegas, E., Toledo-Alarcón, J., Ruiz-Filippi, G., 2015. Simultaneous production and separation of biohydrogen in mixed culture systems by continuous dark fermentation. Water Sci Technol. J. Int. Assoc. Water Pollut. Res. 71, 1271-1285. https://doi.org/10.2166/wst.2015.104.

Raunkjær, K., Hvitved-Jacobsen, T., Nielsen, P.H., 1994. Measurement of pools of protein, carbohydrate and lipid in domestic wastewater. Water Res. 28, 251262. https://doi.org/10.1016/0043-1354(94)90261-5.

Ravot, G., Ollivier, B., Magot, M., Patel, B., Crolet, J., Fardeau, M., Garcia, J., 1995 Thiosulfate reduction, an important physiological feature shared by members of the order thermotogales. Appl. Environ. Microbiol. 61, 2053-2055.

Rinker, K.D., Kelly, R.M., 2000. Effect of carbon and nitrogen sources on growth dynamics and exopolysaccharide production for the hyperthermophilic archaeon Thermococcus litoralis and bacterium Thermotoga maritima. Biotechnol. Bioeng. 69, 537-547. https://doi.org/10.1002/1097-0290 (20000905)69:5<537::AID-BIT8>3.0.CO;2-7.

Romano, R.T., Zhang, R., 2008. Co-digestion of onion juice and wastewater sludge using an anaerobic mixed biofilm reactor. Bioresour. Technol. 99, 631-637. https://doi.org/10.1016/j.biortech.2006.12.043.

Ruggeri, B., Tommasi, T., 2012. Efficiency and efficacy of pre-treatment and bioreaction for bio-H2 energy production from organic waste. Int. J. Hydrog. Energy 37, 6491-6502. https://doi.org/10.1016/j.ijhydene.2012.01.049.

Schröder, C., Selig M. Schönheit, P. 1994. Glucose fermentation to acetate CO2 and $\mathrm{H} 2$ in the anaerobic hyperthermophilic eubacterium Thermotoga maritima: involvement of the Embden-Meyerhof pathway. Arch. Microbiol. 161, 460-470.
Schut, G.J., Lipscomb, G.L., Han, Y., Notey, J.S., Kelly, R.M., Adams, M.M.W., 2014. The order thermococcales and the family thermococcaceae. In: Rosenberg, E., DeLong, E.F., Lory, S., Stackebrandt, E., Thompson, F. (Eds.), The Prokaryotes. Springer, Berlin Heidelberg, Berlin, Heidelberg, pp. 363-383.

Shafiee, S., Topal, E., 2009. When will fossil fuel reserves be diminished? Energy Policy 37, 181-189. https://doi.org/10.1016/j.enpol.2008.08.016.

Sun, X.F., Sun, R.C., Tomkinson, J., Baird, M.S., 2003. Preparation of sugarcane bagasse hemicellulosic succinates using NBS as a catalyst. Carbohydr. Polym. 53, 483-495. https://doi.org/10.1016/S0144-8617(03)00150-4.

Tenca, A., Schievano, A., Perazzolo, F., Adani, F., Oberti, R., 2011. Biohydrogen from thermophilic co-fermentation of swine manure with fruit and vegetable waste: Maximizing stable production without $\mathrm{pH}$ control. Bioresour. Technol. 102, 8582-8588. https://doi.org/10.1016/j.biortech.2011.03.102.

Turner, J.A., 2004. Sustainable hydrogen production. Science 305, 972-974. https:// doi.org/10.1126/science.1103197.

Ueda, Y., Tsubuku, T., Miyajima, R., 1994. Composition of sulfur-containing components in onion and their flavor characters. Biosci. Biotechnol. Biochem. 58, 108-110. https://doi.org/10.1271/bbb.58.108.

Wu, B., Tseng, C.K., Xiang, W., 1993. Large-scale cultivation of Spirulina in seawater based culture medium. Bot. Mar. 36, 99-102.

Yadvika, null, Santosh, null, Sreekrishnan, T.R., Kohli, S., Rana, V., 2004 Enhancement of biogas production from solid substrates using different techniques - a review. Bioresour. Technol. 95, 1-10, doi:10.1016/j. biortech.2004.02.010.

Zhang, Y., Shen, J., 2006. Effect of temperature and iron concentration on the growth and hydrogen production of mixed bacteria. Int. J. Hydrog. Energy 31, 441-446. https://doi.org/10.1016/j.ijhydene.2005.05.006. 